\title{
Determining the Pace and Magnitude of Lake Level Changes in Southern Ethiopia Over the Last 20,000 Years Using Lake Balance Modeling and SEBAL
}

\begin{abstract}
Markus L. Fischer ${ }^{1,2 *}$, Monika Markowska ${ }^{1,3}$, Felix Bachofer ${ }^{4}$, Verena E. Foerster ${ }^{5}$, Asfawossen Asrat ${ }^{6}$, Christoph Zielhofer ${ }^{7}$, Martin H. Trauth ${ }^{8}$ and Annett Junginger ${ }^{1,2}$

${ }^{1}$ Department of Geosciences, Eberhard Karls University Tübingen, Tübingen, Germany, ${ }^{2}$ Senckenberg Centre for Human Evolution and Paleoenvironment (S-HEP), Tübingen, Germany, ${ }^{3}$ Department of Climate Geochemistry, Max Planck Institute for Chemistry, Mainz, Germany, ${ }^{4}$ Earth Observation Centre, German Aerospace Center (DLR), Wessling, Germany, ${ }^{5}$ Institute of Geography Education, University of Cologne, Cologne, Germany, ${ }^{6}$ School of Earth Sciences, Addis Ababa University, Addis Ababa, Ethiopia, ${ }^{7}$ Institute of Geography, University of Leipzig, Leipzig, Germany, ${ }^{8}$ Institute of Geosciences, University of Potsdam, Potsdam, Germany
\end{abstract}

OPEN ACCESS

Edited by:

David K. Wright,

University of Oslo, Norway

Reviewed by: Nick Andrew Drake,

King's College London,

United Kingdom

Seifu Admassu Tilahun,

Bahir Dar University, Ethiopia

Sylvia G. Dee,

Rice University, United States

${ }^{*}$ Correspondence:

Markus L. Fischer

markus_fischer@posteo.de

Specialty section

This article was submitted to Quaternary Science, Geomorphology and Paleoenvironment,

a section of the journal

Frontiers in Earth Science

Received: 12 March 2020 Accepted: 18 May 2020

Published: 30 June 2020

Citation:

Fischer ML, Markowska M, Bachofer F, Foerster VE, Asrat A, Zielhofer $\mathrm{C}$, Trauth $\mathrm{MH}$ and Junginger A (2020) Determining the Pace and Magnitude of Lake Level Changes in

Southern Ethiopia Over the Last

20,000 Years Using Lake Balance Modeling and SEBAL.

Front. Earth Sci. 8:197.

doi: 10.3389/feart.2020.00197
The Ethiopian rift is known for its diverse landscape, ranging from arid and semi-arid savannahs to high and humid mountainous regions. Lacustrine sediments and paleo-shorelines indicate water availability fluctuated dramatically from deep fresh water lakes, to shallow highly alkaline lakes, to completely desiccated lakes. To investigate the role lakes have played through time as readily available water sources to humans, an enhanced knowledge of the pace, character and magnitude of these changes is essential. Hydro-balance models are used to calculate paleo-precipitation rates and the potential pace of lake level changes. However, previous models did not consider changes in hydrological connectivity during humid periods in the rift system, which may have led to an overestimation of paleo-precipitation rates. Here we present a comprehensive hydro-balance modeling approach that simulates multiple rift lakes from the southern Ethiopian Rift (lakes Abaya, Chamo, and paleo-lake Chew Bahir) simultaneously, considering their temporal hydrological connectivity during high stands of the African Humid Period (AHP, 15-5 ka). We further used the Surface Energy Balance Algorithm for Land (SEBAL) to calculate the evaporation of paleo-lake Chew Bahir's catchment. We also considered the possibility of an additional rainy season during the AHP as previously suggested by numerous studies. The results suggest that an increase in precipitation of $20-30 \%$ throughout the southern Ethiopian Rift is necessary to fill paleo-lake Chew Bahir to its overflow level. Furthermore, it was demonstrated that paleo-lake Chew Bahir was highly dependent on the water supply from the upper lakes Abaya and Chamo and dries out within $\sim 40$ years if the hydrological connection is cut off and the precipitation amount decreases to present day conditions. Several of such rapid lake level fluctuations, from a freshwater to a saline lake, might have occurred during the termination of the AHP, when humid conditions were less stable. Fast changes in fresh water availability requires high adaptability for humans living in the area and might have exerted severe environmental stress on humans in a sub-generational timescale.

Keywords: African humid period, precipitation changes, abrupt and gradual changes, Chew Bahir, Lake Abaya, Lake Chamo, human-environment interaction 


\section{INTRODUCTION}

Eastern African precipitation is characterized by large interannual to centennial variability (Lamb et al., 1998; Nicholson, 2000; Junginger et al., 2014; Liu et al., 2017), controlling water resource availability in the region. This is accentuated by the uneven spatial distribution of precipitation, from the lowlands $(<500 \mathrm{~m})$ to the high plateaus $(>4,000 \mathrm{~m})$, due to the extreme topography of the East African Rift System (EARS) (Nicholson, 2017). In recent decades a decline in precipitation has led to an increase in the intensity and frequency of drought periods (Funk et al., 2008; Viste, 2012; Rowell et al., 2015).

Water availability has always played a fundamental role in eastern Africa, and fluctuations in eastern Africa's hydroclimate in the past have had a dramatic impact on human societies. Changes in orbital insolation during the late Pleistocene to Middle Holocene caused an "African Humid Period" (AHP; 15-5 ka BP; deMenocal et al., 2000; Barker et al., 2004), when increased precipitation triggered changes in vegetation (Lamb et al., 2004), dust dynamics (Zielhofer et al., 2017), lake expansion and increased river flow (Barker et al., 2004; Costa et al., 2014; Revel et al., 2014; Bloszies et al., 2015). In the wider region, these environmental changes during the AHP have been associated with multiple migration dynamics, such as the reoccupation of the Sahara $\sim 10.5$ ka BP (Kuper and Kröpelin, 2006; Drake et al., 2013; Larrasoaña et al., 2013; Manning and Timpson, 2014), cultural innovation (Lario et al., 1997) and overlapped with a demographic transition to the Neolithic age (Manning and Timpson, 2014; Honegger and Williams, 2015). An increase in arid conditions has been documented during the termination of the AHP $\sim 5 \mathrm{ka}$ BP in eastern Africa (e.g., deMenocal et al., 2000; Barker et al., 2004; Foerster et al., 2012; Junginger et al., 2014; Bloszies et al., 2015). This aridification trend coincides with societal adaptations, such as the introduction of pastoralism to eastern Africa, and the emergence of highly organized and complex state-level societies (demenocal, 1995; Brooks, 2006; Kuper and Kröpelin, 2006; Garcin et al., 2012; Foerster et al., 2015). Environmental changes likely provide both opportunities and constraints, due to variability in water resources and food availability, necessitating adaptation. To better understand potential links between cultural changes and climate variability, paleoclimate records can be used in conjunction with archaeological records to reconstruct major influences on modern civilizations.

In eastern Africa, however, there are still spatial and chronological gaps in paleoclimate records, which are largely non-quantitative and often regionally specific. Discrepancies particularly occur between records from marine archives, and lacustrine sites and also whether lacustrine sites are located within or outside the EARS. Existing records covering the AHP, report conflicting accounts of past climate variability in the region, with some studies suggesting a rapid onset and termination of the AHP (deMenocal et al., 2000; Tierney et al., 2013; Collins et al., 2017), while others indicate a rapid onset but more gradual termination and climate evolution in response to insolation forcing (Renssen et al., 2006; Asrat et al., 2007; Foerster et al., 2012; Junginger et al., 2014; Trauth et al., 2018). While lakes with a constant groundwater/geothermal supply were mostly stable (e.g., Lake Tilo on the Ethiopian Plateau, Telford and Lamb, 1999), river-fed EARS lakes, such as Chew Bahir or ZiwayShala in Ethiopia (Gillespie et al., 1983; Foerster et al., 2012) or Lakes Elementeita-Nakuru (Richardson and Dussinger, 1986), paleo-Lake Suguta in Kenya (Junginger et al., 2014) or Lake Manyara (Bachofer et al., 2015) demonstrated greater variability in lake levels in response to short-term precipitation-evaporation changes (Figure 1).

The first steps toward quantifying precipitation rates during the AHP and lake responses to a changing precipitationevaporation budget were conducted for several basins in the EARS by applying Lake Balance Modeling (LBM) (Figure 1; Hastenrath and Kutzbach, 1983; Bergner et al., 2003; Dühnforth et al., 2006; Kniess, 2006; Borchardt and Trauth, 2012; Junginger and Trauth, 2013). LBM uses field observations, such as ${ }^{14} \mathrm{C}$ dated shorelines and overflow sills high above modern lakes (indicative of higher moisture availability), to calculate paleo-lake volumes, levels and paleo-precipitation rates. Such attempts of quantifying environmental parameters using field observations (e.g., shorelines) or proxy data (e.g., leaf waxes, stable isotopes, dust, pollen) through modeling approaches are defined as socalled Proxy System Modeling (PSM), as presented by Evans et al. (2013) or Dee et al. (2018).

For the AHP, the reconstruction of environmental parameters, such as paleo-temperatures, is based for example on GDGT and Tex 86 proxies from lake sediments (e.g., Verschuren, 2004; Berke et al., 2012a; Damsté et al., 2012; Loomis et al., 2012, 2014, 2015). Precipitation reconstructions are usually created using pollen (e.g., Lamb et al., 2004; Vincens et al., 2005; Umer et al., 2007; Rucina et al., 2009; Marchant et al., 2018), stalagmites (e.g., Baker et al., 2010), leaf waxes (e.g., Berke et al., 2012b; Costa et al., 2014), and the aforementioned LBMs. Due to the lack of the aforementioned proxy data in our study region, Chew Bahir in southern Ethiopia, an LBM is chosen to calculate paleo-precipitation rate changes.

Previously developed LBMs for the EARS, however, only looked at individual basins and therefore did not consider the hydrological connection via surface overflow of many rift basins (Figure 1). Consequently, the hydrological inflow budget of these interconnected lakes may have been underestimated, affecting the calculated paleo-precipitation estimates from the LBMs. Another aspect that was not considered in previous LBMs is change in seasonality. For the AHP it is hypothesized that an additional rainy season developed due to a shift of the Congo Air Boundary $(\mathrm{CAB})$ during the northern hemisphere summer months, therefore tremendously impacting seasonality, environment and associated feedback mechanisms (e.g., Junginger and Trauth, 2013; Costa et al., 2014; Bloszies et al., 2015; Beck et al., 2019).

Here we present a comprehensive hydro-balance modeling approach that simulates firstly multiple rift lakes from the southern Ethiopian Rift (Figure 1; Abaya, Chamo, Chew Bahir). For this purpose, we developed a LBM for the region, which is a further development of the former models (e.g., Blodgett et al., 1997; Lenters and Cook, 1999). We have applied a combined 


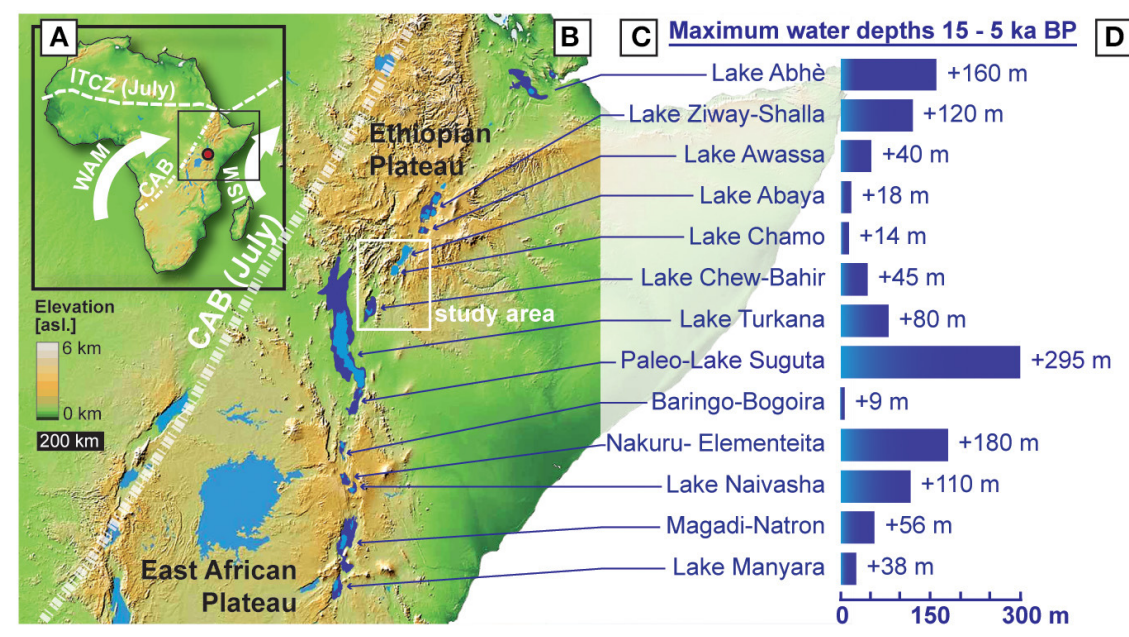

LBM results References

$+28 \% \quad$ Gillespie et al., 1983

$+1 \% \quad$ this study

$+3 \% \quad$ this study

$+21-29 \%$ this study

$+20 \% \quad$ Hastenrath and Kutzbach, 1983

+21-26\% Borchardt and Trauth, 2012; Junginger and Trauth, 2013

+23-45\% Dühnforth et al., 2006; Kniess, 2006

$+29-33 \% \quad$ Hastenrath \& Kutzbach, 1983; Bergner et al., 2003

E



FIGURE 1 | Overview of the study area, lake levels and lake-balance modeling results from previous an current studies: (A) Elevation map of Africa and the positions of major air boundaries and convergence zones during the NH summer. Indian Summer Monsoon (ISM), West African Monsoon (WAM), the Inter Tropical Convergence Zone (ITCZ), and Congo Air Boundary (CAB). (B) Elevation map of eastern Africa with the study area, major lakes, study area (white box) and the CAB position in July. (C,D) Known paleo-lake depths within the EARS during the African Humid Period (AHP) and published paleo-precipitation rates estimates using different lake-balance approaches and associated references. (E) Transect of the EARS from north-east to south, with modern and paleo level lake extents (light and dark blue, respectively), the study area (red box), and major drainage direction (dotted line). North-South transect of the eastern branch of the EARS, with modern and paleo-lake extents (light and dark blue, respectively), the study area (red box), and major drainage direction (dotted line). The figure was modified after Junginger and Trauth (2013).

catchment approach including surface and subsurface flows. Two approaches were used to estimate the evapotranspiration; a bulk transfer equation and the Surface Energy Balance Algorithm for Land (SEBAL). The paleo-precipitation required during the AHP to fill lakes to their previous high-stands will be calculated under different scenarios including the incorporation of an additional rainy season as previously suggested by multiple studies (e.g., Junginger et al., 2014; Bloszies et al., 2015; Beck et al., 2019) and the theoretical feedback due to vegetation changes. We furthermore provide lake regression and transgression times under abrupt and gradual changes, in order to demonstrate the sensitivity of the investigated lake systems to changes in precipitation. Based on the outcome of the model, we compare lake response times to abrupt and gradual precipitation changes to aridity proxy data of an $11 \mathrm{~m}$-long sediment core from the margin of paleo-lake Chew Bahir, which was published by Foerster et al. (2015) to reconstruct the paleo-lake level evolution of Chew Bahir during the past $20 \mathrm{ka}$.

\section{REGIONAL SETTING}

\section{The Investigated Catchments}

There are three adjoining North-South trending, endorheic basins at the southern end of the Main Ethiopian Rift (MER) which are part of the greater $(4,000 \mathrm{~km})$ EARS. These are the basins of Lake Abaya, Lake Chamo, and paleo-lake Chew Bahir, from north to south, respectively (Figure 1). Lake Abaya $\left(6.4^{\circ} \mathrm{N}\right.$, $37.95^{\circ} \mathrm{E}, 7 \mathrm{~m}$ deep, and lake surface area of $\left.1,081 \mathrm{~km}^{2}\right)$ is the northern-most and highest elevated $(1,176 \mathrm{~m}$ a.s.l.) basin with a catchment size of $16,203 \mathrm{~km}^{2}$ (Figure 2). The major rivers draining into Lake Abaya include the Gelana, Bilate, Gidabo, Hare, Baso, and Amesa Rivers (Tiruneh, 2005). Lake Chamo $\left(5.8^{\circ} \mathrm{N}, 37.6^{\circ} \mathrm{E}, \sim 1,109 \mathrm{~m}\right.$ a.s.l., $14 \mathrm{~m}$ deep, $310 \mathrm{~km}^{2}$ lake surface area) to the south is separated from Lake Abaya by the Quaternary Tosa Sucha Volcano (Ebinger et al., 1993; Figure 2J). The Kulfo River to the west is the main tributary, while Sile and Wezeka rivers are smaller tributaries into Lake Chamo (Tiruneh, 2005). The Kulfo River is also connected to Lake 


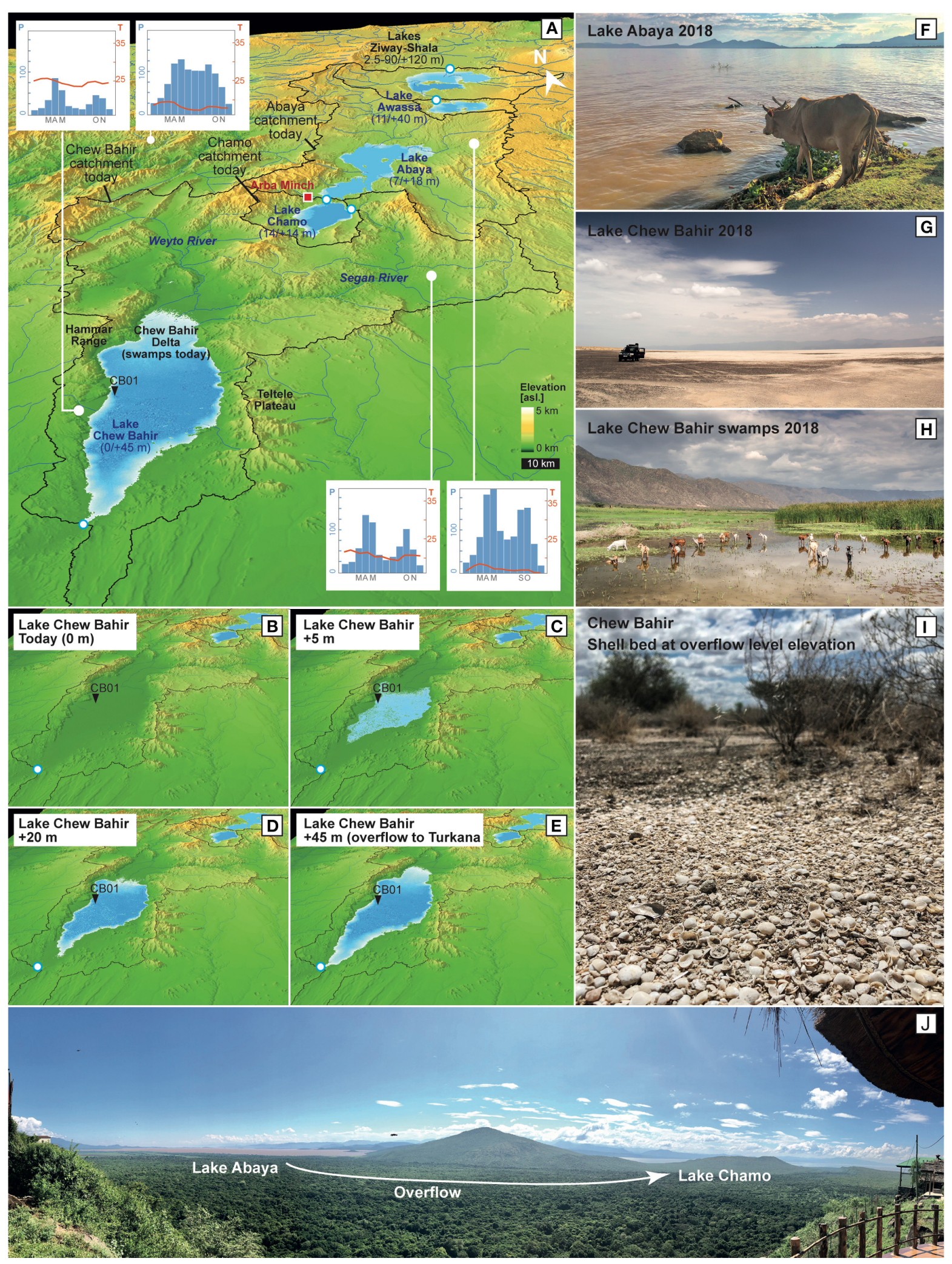

FIGURE 2 | Geographical features of the studied lake basins: (A) Modern catchment boundaries, monthly temperature means in ${ }^{\circ} \mathrm{C}$ and precipitation in mm/month (IRI, last accessed 11/2019), overflow sill locations (white-blue circles), and paleo-lake dimensions with modern/paleo-depths in numbers. (B-E) Modeling outputs of paleo-lake Chew Bahir's dimension during different lake filling steps from modern to $+5,+20$, and $+45 \mathrm{~m}$ when reaching the overflow level. (F-J) Pictures from study sites by $A$. Junginger. 
Abaya during wet periods when lake levels are higher (Tiruneh, 2005). The catchment area of Lake Chamo is $\sim 1,793 \mathrm{~km}^{2}$. Both lakes, Chamo and Abaya are bounded by the Gamo-Gidole horst to the west and the Amaro horst to the east reaching elevations over 3,000 $\mathrm{m}$ a.s.l. and consisting mainly of Cenozoic rift volcanics unconformably overlaying Precambrian basement rocks (Davidson, 1983; Ebinger et al., 1993). Paleo-lake Chew Bahir $\left(4.1-6.3^{\circ} \mathrm{N}, 36.5-38.1^{\circ} \mathrm{E}, \sim 498 \mathrm{~m}\right.$ a.s.l, Figures 1, 2) to the south is most of the year a $210 \mathrm{~km}^{2}$ saline mudflat and the lowest in elevation of the herein investigated basins. The Chew Bahir surface comprises deltaic ephemeral swamps at its northerly and north easterly reaches, where the perennial Weyto and Segan rivers drain the north-western and north-eastern sides of the catchment, respectively (Figure 2). The catchment (20,650 $\mathrm{km}^{2}$ ) is bound by the MER rift shoulders, in the east by the Teltele Plateau (up to $1,600 \mathrm{~m}$ a.s.l.) and in the west by the Hammar Range (up to $1,300 \mathrm{~m}$ a.s.l.). The elevation of the rift shoulders decreases in a southerly direction. The northern side of the catchment is bound by uplifted Proterozoic metamorphic rocks and Cenozoic rift volcanics (Davidson, 1983; Figures 1, 2), hydrologically separating it from the Chamo and Abaya catchments. To the south, Cenozoic rift volcanics from the foothills of the Hammar Range prevent a direct hydrological link with the Turkana basin, today. The dry southern-most part of the catchment borders Kenya.

\section{Overflow Regime}

Several paleo-shorelines, wave cut notches and sediment characteristics in the Ethiopian Rift and plateau regions, such as Lake Abhé (Gasse and Street, 1978), Lake Ziway-Shala-Abiyata (Gillespie et al., 1983; Chalié and Gasse, 2002), Lake Dendi (Wagner et al., 2018), or Lake Ashenge (Marshall et al., 2009) show evidence of deep lakes during the AHP. During those high stands, these lakes were overflowing into rivers that connected to other lake basins. Awulachew (2006) reported that lakes Abaya and Chamo were previously connected via surface streams. Here, Lake Abaya connected via an old channel through the Kulfo river with Lake Chamo (Figure 2). Awulachew (2006) and Kassa (2015) report of evidence that during high stands, Lake Chamo overflowed into the river Metenafesha and into the Sermale stream, both being tributaries of the Segan river, which in turn feeds paleo-lake Chew Bahir. During a field campaign in November 2018, paleo-shoreline deposits (shell beds) at Chew Bahir could be identified at the same elevation as the overflow sill (Figure 2). As calculated in section Digital Elevation Model Analysis, Lake Abaya's overflow sill to the Chamo catchment is at $1,194 \mathrm{~m}$ a.s.1. $\left(6^{\circ} 0^{\prime} 40.38^{\prime \prime} \mathrm{N}, 37^{\circ} 34^{\prime} 50.45^{\prime \prime} \mathrm{E}\right) 18 \mathrm{~m}$ above its present lake level. Lake Chamo reaches its overflow sill to the Chew Bahir catchment at $1,123 \mathrm{~m}$ a.s.l. $\left(5^{\circ} 51^{\prime} 49.66^{\prime \prime} \mathrm{N}\right.$, $37^{\circ} 38^{\prime} 31.78^{\prime \prime} \mathrm{E}$ ), which is $14 \mathrm{~m}$ above its modern lake surface. The Chew Bahir basin has an overflow sill at $543 \mathrm{~m}$ a.s.l. $\left(4^{\circ} 13^{\prime} 30.58^{\prime \prime} \mathrm{N}, 36^{\circ} 39^{\prime} 35.19^{\prime \prime} \mathrm{E}\right)$ to Lake Turkana, $45 \mathrm{~m}$ above the basin floor.

\section{Vegetation}

Modern vegetation in the Chew Bahir catchment is typically sparse and follows an east-west gradient (Friis et al., 2010). The eastern part of the Chew Bahir basin is classified as AcaciaCommiphora woodland and bushland, whereas the western part is described as Combretum-Terminalia woodland and wooded grassland (Friis et al., 2010). The higher elevated parts of the study area, such as close to Arba Minch (Figure 2), comprise evergreen Afro-Montane forest and grassland complex, which transitions to moist evergreen Afro-Montane forest in the north. The vegetation in the even higher mountainous areas are dominated by Afro-alpine vegetation with an Ericaceous Belt (Friis et al., 2010).

\section{Climate}

Seasonal rainfall in Chew Bahir is associated with the annual passage of a tropical rain belt (often referred to as the Inter Tropical Convergence Zone, ITCZ), which is predominantly fueled by the Indian Ocean (Figure 1, Levin et al., 2009; Nicholson, 2017). Generally, the tropical rain belt migrates between $10^{\circ}$ North and South of the equator, resulting in a bimodal precipitation pattern close to the equator and an unimodal pattern at its limits (Nicholson, 1996). Consequently, the lower elevations of the Chew Bahir catchment precipitation is bimodal, with the "Belg" rains from March to May (long rains) and the "short rains" in October-November (Figure 2). The highlands northwest of Chew Bahir, including the Abaya and Chamo catchments, experience an unimodal rainfall pattern with only one longer wet season from March to November (Segele and Lamb, 2005; Williams and Funk, 2011). This wet season is, fueled by two different sources, with the "Belg" rains lasting from March to May and the "Kiremt" rains from June to September. The Kiremt rains are hypothesized to originate from the Atlantic Ocean-derived southwestern humid Congo air stream (Nicholson, 1996; Camberlin, 1997; Lamb et al., 2000). The eastern limit of this air stream is marked by the Congo Air Boundary, which separates the humid air masses from the west from dry air masses in the east (Nicholson, 1996). Annual to decadal fluctuations in the intensity and strength of precipitation are possibly related to a direct response to seasurface temperature variations in the Indian and Atlantic Oceans (Nicholson, 2017). Compared to other areas at similar latitudes in Africa, Ethiopia receives considerably more rainfall due to its position in the MER and the resulting orographic effects (Nicholson, 2017).

\section{MATERIALS AND METHODS}

We developed a LBM to quantify the present day and paleowater balances of paleo-lake Chew Bahir, Lake Chamo and Lake Abaya. The model was coded in $\mathrm{R}$ and is available at GitHub (https://github.com/MLFischer/Lake-Balance-Model, 03/2019). In summary, a Digital Elevation Model (DEM) was used to delineate the catchment boundaries, lake bathometry, lake volumes and overflow sills (section Digital Elevation Model Analysis). The annual modern water balances were calculated for Lakes Abaya, Chamo and paleo-lake Chew Bahir (section Lake Balance of Lakes Abaya, Chamo, and Paleo-Lake Chew Bahir). Evaporation was estimated for the paleo-lake Chew Bahir catchment using SEBAL [section Surface Energy Balance 
Algorithm for Land (SEBAL)]. After parametrizing the model based on present-day conditions, we modeled the most recent lake high-stands of Lake Chamo, Abaya and paleo-lake Chew Bahir during the AHP (section Paleo-Lake Modeling). In section Calculation of Amplifier Lake Characteristics, we calculated the Hypsometric Integral (HI) and Aridity Index (AI) for the paleolake Chew Bahir, Lake Abaya and Chamo catchments which are used to define the Amplifier Lake characteristic of lake basins in the EARS following Olaka et al. (2010). In section Lake Level Reconstruction of Paleo-Lake Chew Bahir, we apply the modeled lake responses of paleo-lake Chew Bahir to various changes is precipitation and thus lake-level scenarios to changes in a $\mathrm{K}$ proxy record from a drill-core taken from the paleo-lake Chew Bahir basin (Foerster et al., 2012, 2015; Trauth et al., 2018) and reconstruct the paleo-lake level of the past $20 \mathrm{ka}$.

\section{Digital Elevation Model Analysis}

The catchment boundary delineation was based on the DEM resulting from the Shuttle Radar Topography Mission (SRTM C-band; http://www2.jpl.nasa.gov/srtm/). The flow directions, flow accumulations, catchment boundaries and hydro-junctions (maximum possible lake extent) were calculated with the workflow for deranged terrains from the ArcHydro toolbox of ArcGIS 10.3 (Merwade, 2012). The DEM of each catchment was processed using the freq function in the $\mathrm{R}$ raster-package to produce an elevation frequency table, which then is used to compute the basin hypsometry and paleo-lake bathymetry ( $R$ Core Team, 2019).

\section{Lake Balance Model}

Three processing steps were applied for calculating the modern day annual water balance as later summarized in Equation (3). The parameters used in this model are climate parameter based on interpolated global gridded climate data (New et al., 2002), remote sensing data (Friedl et al., 2010; Platnick et al., 2015) and evaporation parametrization approaches (Schmugge and André, 1991). The input parameters are annual averages and they are summarized in Table 1.
The first was to calculate surface temperatures by a radiationbased surface energy flux (Equation 1). The energy balance was calculated using Newton's method to determine the surface temperature. The energy fluxes were assumed to be in an equilibrium state and include: the incoming short-wave radiation $\left(R_{s w}\right)$, the incoming long-wave radiation $\left(R_{l d}\right)$ with the surface emissivity $(\varepsilon)$, the long-wave radiation $\left(R_{l u}\right)$ emitted by the Earth's surface, the sensible heat flux $(H)$ and the latent heat flux $\left(L \cdot E T_{a}\right.$ ), with $L$ being the latent heat of vaporization, and $E T_{a}$ the rate of actual evaporation (Blodgett et al., 1997; Lenters and Cook, 1999).

$$
\mathrm{R}_{\mathrm{sw}}-\mathrm{R}_{\mathrm{lu}}+\epsilon \mathrm{R}_{\mathrm{ld}}-\mathrm{H}-\mathrm{L} \cdot \mathrm{ET}_{\mathrm{a}}=0
$$

In the second step (Equation 2), $E T_{a}$ was calculated using the bulk transfer formula described by Brutsaert (1982), with the surfacedrag coefficient $\left(C_{D}\right)$, the wind speed $(U)$, the soil moisture availability $(f)$, the gas constant for dry air $(R)$, the surface $\left(T_{s}\right)$ and air $\left(T_{a}\right)$ temperatures, the relative humidity $(r h)$, and the saturation vapor pressure $\left(e s\left(T_{s}\right)\right)$ as a function of surface and air temperature.

$$
\mathrm{ET}_{\mathrm{a}}=\frac{0.622 \cdot \mathrm{C}_{\mathrm{D}} \cdot \mathrm{U} \cdot \mathrm{f}}{R T_{a}}\left[\mathrm{es}\left(\mathrm{T}_{\mathrm{s}}\right)-\mathrm{rh} \cdot \mathrm{es}\left(\mathrm{T}_{\mathrm{a}}\right)\right]
$$

The resulting $E T_{a}$ on land and water was calculated with Equations (1) and (2) from the environmental parameters summarized in Table 1. A sensitivity analysis of $E T_{a}$ for paleolake Chew Bahir to major environmental parameters, such as air temperature $\left(T_{a}\right)$, cloud cover, relative humidity $(r h)$, and wind speed $(U)$ was performed.

The third step involved calculating the annual lake water balance of lakes Abaya, Chamo and paleo-lake Chew Bahir using $E T_{a}$ on land $\left(E_{l}\right)$ and water $\left(E_{w}\right)$, the precipitation amount from the Tropical Rainfall Measuring Mission (TRMM, Bookhagen, in review) $\left(P_{b a s}\right)$ and the basin-wide subsurface outflow/inflow $\left(S_{\text {bas }}\right)$ following Equation (3). A positive and negative water balance suggest an increase and decrease in lake water volume,

\begin{tabular}{|c|c|c|c|c|c|c|c|c|c|}
\hline \multirow[t]{2}{*}{ Parameter } & \multirow[t]{2}{*}{ Symbol (Unit) } & \multicolumn{2}{|c|}{ Chew Bahir } & \multicolumn{2}{|c|}{ Chamo } & \multicolumn{2}{|c|}{ Abaya } & \multirow[t]{2}{*}{ Confidence } & \multirow[t]{2}{*}{ References } \\
\hline & & Lake & Land & Lake & Land & Lake & Land & & \\
\hline Cloud free shortwave radiation & R_sw $\left(W / m^{2}\right)$ & 415 & & 415 & & 415 & & \pm 3 & Berger and Loutre, 1991 \\
\hline Shortwave cloud parameters & $a, b$ & $0.39,0.38$ & & $0.39,0.38$ & & $0.39,0.38$ & & - & Bookhagen et al., 2001 \\
\hline Longwave cloud parameters & a_2, b_2 & $0.22,2.0$ & & $0.22,2.0$ & & $0.22,2.0$ & & - & Bookhagen et al., 2001 \\
\hline Air pressure & $\mathrm{p}(\mathrm{kPa})$ & 95.67 & 88.5 & 88.7 & 85.13 & 87.9 & 81.7 & - & Barometric elevation formula \\
\hline Cloud coverage & $\mathrm{CC}$ & 0.44 & 0.61 & 0.37 & 0.55 & 0.31 & 0.54 & \pm 0.05 & Platnick et al., 2015 \\
\hline Relative humidity & $\mathrm{rh}$ & 0.55 & 0.57 & 0.57 & 0.57 & 0.57 & 0.58 & \pm 0.05 & New et al., 2002 \\
\hline Windspeed & $w s\left(\mathrm{~m} \mathrm{~s}^{-1}\right)$ & 2.56 & 2.13 & 1.71 & 1.72 & 1.46 & 1.42 & \pm 0.3 & New et al., 2002 \\
\hline Air temperature & t_a $\left({ }^{\circ} \mathrm{C}\right)$ & 26.35 & 22.75 & 21.95 & 20.15 & 21.55 & 18.35 & \pm 0.5 & New et al., 2002 \\
\hline Surface drag coefficient & cds & $7.3 \times 10^{-4}$ & $5.9 \times 10^{-3}$ & $7.3 \times 10^{-4}$ & $6.6 \times 10^{-3}$ & $7.3 \times 10^{-4}$ & $7.6 \times 10^{-3}$ & $\pm 0.2 \times 10^{-3}$ & Schmugge and André, 1991 \\
\hline Surface albedo & albedo & 0.06 & 0.14 & 0.06 & 0.126 & 0.06 & 0.136 & \pm 0.02 & Friedl et al., 2010 \\
\hline Surface emissivity & emis & 0.98 & 0.96 & 0.98 & 0.96 & 0.98 & 0.96 & \pm 0.02 & Friedl et al., 2010 \\
\hline Moisture availability & $f$ & 1.00 & 0.137 & 1.00 & 0.198 & 1.00 & 0.25 & \pm 0.05 & Schmugge and André, 1991 \\
\hline
\end{tabular}

TABLE 1 | Summary of input parameters for the LBM of Chew Bahir, Chamo, and Abaya. 
respectively. The modern-day conditions of Lake Abaya, Lake Chamo and paleo-lake Chew Bahir were assumed to be in equilibrium, where $\Delta \mathrm{V}=0$ as suggested in previous studies, such as Bookhagen et al. (2001), Bergner et al. (2003), and Junginger and Trauth (2013). The water surplus was assumed to be groundwater recharge in contrast to previous LBM studies, which used a fixed precipitation to groundwater ratio (Blodgett et al., 1997), a fix value (Bergner et al., 2003) or that the groundwater recharge rate is zero (e.g., Bookhagen et al., 2001; Dühnforth et al., 2006; Junginger and Trauth, 2013).

$$
\Delta \mathrm{V}_{\text {lake }}=\mathrm{P}_{\text {bas }}-\left[\mathrm{E}_{\mathrm{w}} \alpha_{\mathrm{w}}+\mathrm{E}_{\mathrm{l}}\left(1-\alpha_{\mathrm{w}}\right)\right]-\mathrm{S}_{\mathrm{bas}}=0
$$

\section{The SEBAL Method}

Southern Ethiopia is a data-sparse region, with few continuously monitored weather stations, making quantification of the evaporation difficult on a catchment scale. Hence, we used a second approach called Surface Energy Balance Algorithm for Land (SEBAL; Bastiaanssen et al., 1998a,b). SEBAL calculates the Earth's surface instantaneous energy flux (Equation 4) at the moment of satellite overpass, to determine the latent heat flux as the residual (Bastiaanssen et al., 1998a,b).

In order to populate the SEBAL input parameters, satellite remote sensing data products of the Moderate-Resolution Imaging Spectroradiometer (MODIS) were identified and resampled to an uniform spatial resolution of $500 \mathrm{~m}$ (Table 2). To quantify monthly evaporation (Zhang et al., 2011; Borchardt and Trauth, 2012), the available MODIS datasets for an average reference year (2010 CE, Kiptala et al., 2013) were processed. The selection criterion applied was a clear sky coverage of higher than 90 percent. The Land Cover MCD12Q1 was further utilized to estimate the surface roughness length and the surface drag coefficient, following Wieringa (1992).

To calculate $\mathrm{ET}_{\mathrm{a}}$ based on the surface energy fluxes we employed the net radiation $\left(R_{n}\right)$ equation (Equation 4$)$. $\mathrm{ET}_{\mathrm{a}}$ was

TABLE 2 | Moderate-Resolution Imaging Spectroradiometer (MODIS) products and bands used for SEBAL calculation.

\begin{tabular}{|c|c|c|c|c|}
\hline Product & Band & $\begin{array}{l}\text { Temporal } \\
\text { granularity }\end{array}$ & Pixel size (m) & $\begin{array}{l}\text { Data } \\
\text { references }\end{array}$ \\
\hline \multirow[t]{5}{*}{ MOD11A1 } & $\begin{array}{l}\text { Land Surface } \\
\text { Temperature Daily }\end{array}$ & Daily & 1,000 & $\begin{array}{l}\text { Wan et al., } \\
2015\end{array}$ \\
\hline & Emissivity Band 31 & & & \\
\hline & Emissivity Band 32 & & & \\
\hline & Day View Time & & & \\
\hline & Clear Day Coverage & & & \\
\hline \multirow[t]{3}{*}{ MOD09GA } & $\begin{array}{l}\text { Surface Reflectance } \\
\text { Band 1-7 }\end{array}$ & Daily & 500 & $\begin{array}{l}\text { Vermote and } \\
\text { Wolfe, } 2015\end{array}$ \\
\hline & Solar Azimuth & & & \\
\hline & Solar Zenith & & & \\
\hline MOD13Q1 & NDVI & 16 day & 250 & Didan, 2015 \\
\hline MCD12Q1 & $\begin{array}{l}\text { Land Cover Type } 2 \\
\text { (UMD) }\end{array}$ & Yearly & 500 & $\begin{array}{l}\text { Friedl et al., } \\
2010\end{array}$ \\
\hline
\end{tabular}

calculated using the soil heat flux $G$, which accounts for the amount of radiant energy released or absorbed at the soil surface per unit time, the sensible heat flux $H$ and the latent heat flux $\lambda E$, which resolves as residual of Equation (4):

$$
R_{n}=G+H+\lambda E
$$

$R_{n}$ was estimated following the clear sky approach described in Allen et al. (2007) as a function of the day of the year, longitude, latitude, altitude, $\alpha, \varepsilon$ and atmospheric emissivity.

$G$ was calculated with Equation (5) as a function of $R_{n}, \alpha$ and the Normalized Difference Vegetation Index (NDVI), which is a standardized proxy for vegetation density and greenness (Bastiaanssen, 2000).

$$
\frac{G}{R_{n}}=\frac{T_{s}}{\alpha}\left(0.0038 \alpha+0.0074 \alpha^{2}\right)\left(a-0.98 \cdot N D V I^{4}\right)
$$

$H$ was determined using Equation (6), with the specific heat of air at a constant pressure $\left(C_{p}\right)$, density of moist air $(p)$, the vertical temperature gradient $(d T)$, and the aerodynamic heat transfer resistance $\left(r_{a h}\right)$ (Bastiaanssen et al., 1998a).

$$
H=\frac{p C_{p} d T}{r_{a h}}
$$

To solve Equation (6) we applied an approach by Zhang et al. (2011) that utilizes the wind field data by New et al. (2002). The frictional velocity and the aerodynamic resistance to heat transport were calculated for each pixel according to the windfield and the logarithmic wind-profile. Both variables converge through an iterative atmospheric stability correction depending on the Monin-Obukov-Length (Bastiaanssen et al., 1998a,b). The resulting calculated $d T$ leads to $H$ (Bastiaanssen et al., $1998 \mathrm{a}, \mathrm{b})$. The evaporation fraction $(\Delta)$ was calculated to solve for daily evaporation $\left(E T_{24}\right)$ from the instantaneous heat fluxes (Bastiaanssen, 2000; Bastiaanssen et al., 2005) with Equation (7).

$$
\Delta=\frac{\lambda E}{R_{n}-G}=\frac{\lambda E}{\lambda E+H}
$$

$E T_{24}$ is a function of daily net radiation $\left(R_{n 24}\right)$ and $\Delta$ (Bastiaanssen, 2000). $R_{n 24}$ was calculated following De Bruin and Stricker (2000) through the integrated sinusoidal daily illumination and the extra-terrestrial solar radiation.

$$
E T_{24}=\frac{86300 \cdot 10^{3}}{\lambda p_{w}} \Delta R_{n 24}
$$

The daily evaporation $\left(E T_{24}\right)$ was averaged each month to calculate the monthly evaporation. Missing data for months with only cloudy days were interpolated from the adjacent months. To calculate $E T_{a}$, we applied a slight modification of the water balance by Thornthwaite and Mather (1955). We defined the modeled monthly evaporation as $E T_{p}$. Following that, we calculated the catchment average $E T_{p}$ per month and compared them to the precipitation average from the TRMM dataset (Bookhagen, in review). Two assumptions have been 
considered when calculating the monthly water balance: (1) The total monthly $E T_{a}$ is smaller than the total monthly precipitation $(P)$ and the available soil water $(S W)$ in the catchment. (2) $50 \%$ of the monthly water surplus, if occurring, is stored in the soil for the next month $(S W)$ and $50 \%$ of the water surplus results in groundwater recharge $(G W)$. In months where $E T_{p}<P$, we set $E T_{a}=E T_{p}$. However, in months where $E T_{p}>P$ the monthly $E T_{a}$ was calculated by multiplying $E T_{p}$ by the ratio of available water and $E T_{p}$ (Thornthwaite and Mather, 1955; Borchardt and Trauth, 2012). The $E T_{a}$ spatial distribution of humid months does not need to be corrected, as it remains the $E T_{p}$ distribution. During dry months $E T_{a}$ was further modified using the normalized Topographic Wetness Index (TWI; Kirkby and Beven, 1979) as shown in Equation (9). This spatial correction factor using the TWI reflects the orographic influence on the soil water distribution.

$$
\begin{aligned}
E T_{a}(x, y)= & E T_{p}(x, y) \cdot\left[T W I_{\text {norm }}(x, y)\right. \\
& \left.+\left(\frac{\sum \text { availableWater }}{\sum \text { potentialEvaporation }}-T W I \_n o r m\right)\right]
\end{aligned}
$$

In a last step, we compared the SEBAL and the bulk transfer LBM derived $E T_{a}$ estimates on land, as well as the subsurface recharge rates for the Chew Bahir catchment to assess the two different approaches. Lake evaporation estimates for Chamo and Abaya were compared to measured pan evaporation data over the years 1985-2005 from the Arba Minch weather station $\left(6^{\circ} 2^{\prime} \mathrm{N}\right.$, $\left.37^{\circ} 33^{\prime} \mathrm{E}\right)$, which is located between lakes Abaya and Chamo (Belete, 2009).

\section{Paleo-Lake Modeling Method Model Calculation}

In order to assess the sensitivity of lake levels to changes in precipitation and the impact of hydrological connectivity between basins, we combined the LBM's of Lake Abaya, Lake Chamo and paleo-lake Chew Bahir. The annual water balance of each catchment (Equation 3) and the consequent lake volumes were calculated to derive the potential change of lake surface areas. Annual changes in the total lake surface area were considered at the end of each annually modeled time-step and the ratio of land and water were adjusted to reflect the new surface evaporation fluxes for each modeled year. Furthermore, at each annual time step the overflow threshold was considered and an additional drainage function was activated if the lake water level exceeded the height of the overflow sill that was calculated in the DEM analysis (section Digital Elevation Model Analysis). For example, if the surface water level for Lake Abaya equals the overflow threshold, the water surplus is accounted for as inflow into the Chamo catchment and added to the water balance. The TRMM derived precipitation rates were multiplied by the total area of each catchment to calculate the volume of the total water influx. The computed $E T_{a}$ over water was multiplied by the lake area to derive the evaporated water volume above each lake and the $E T_{a}$ over land was multiplied by the remaining catchment areas to calculate the total $E T_{a}$.

\section{Modeling Increased Precipitation Scenarios}

We modeled various changes in precipitation over the Abaya, Chamo, and Chew Bahir catchments to estimate the increase in precipitation that was required for paleo-lake Chew Bahir to reach its overflow sill, the point where paleo-lake Chew Bahir drained into Lake Turkana during lake high-stands in the AHP (Foerster et al., 2012). Covering both decadal and centennial transitions of paleo-lake Chew Bahir (Trauth et al., 2018), we ran 500-years simulations of the LBM. The precipitation is increasing by $0.1 \%$ in each simulation, providing a total of 300 simulations with modeled precipitation increases from 0 to $30 \%$ of present day. This allowed us to calculate both the transition times for paleo-lake Chew Bahir; to go from "no lake" conditions to a "flooded basin" and the amount of increased precipitation that would be required. In the simulations, the exchange rates between the basins were calculated and the amount of the water volume influx from Lake Abaya to Lake Chamo and Lake Chamo to paleo-lake Chew Bahir were quantified as a proportion of its total water budget. Due to a lack of paleovegetation information and its impact on the actual evaporation and resulting precipitation in the study region for the AHP, we used the estimates of a 7-15\% increased precipitation during the AHP in the Kenyan Rift published by Bergner et al. (2003). Those estimates are presented as vegetation threshold within our results and are based on the same parametrization approach as our LBM and are coming from a comparable landscape composition.

\section{Modeling Seasonality Changes in Precipitation}

Previous studies have suggested a change in the seasonality of precipitation during the AHP, due to a shift in the Congo Air Boundary, resulting in additional precipitation during July to September in equatorial regions in eastern Africa (e.g., Junginger, 2011; Junginger and Trauth, 2013; Costa et al., 2014; Junginger et al., 2014; Bloszies et al., 2015; Beck et al., 2019). This would have resulted in a change of the evaporative potential on land, compared to present day, due to an increased potential moisture source over what were previously dry months $\left(\mathrm{ET}_{\mathrm{p}}>\mathrm{P}\right)$. We calculate the difference between ETa and $\mathrm{ET}_{\mathrm{p}}$ using SEBAL from July to September and add this evaporation amount to Chew Bahir's catchment actual evaporation rate on land. We omit the catchment of the lakes Abaya and Chamo from this procedure as they don't have this modern day lack $\left(\mathrm{ET}_{\mathrm{p}}<\mathrm{P}\right)$ of evaporable water for these months.

\section{Transition Times for Onset and Termination of AHP}

The timing of precipitation change was also modeled using different scenarios to estimate the temporal reaction of paleolake Chew Bahir's volume to abrupt and gradual precipitation changes during the onset and termination of the AHP. The first scenario (S1) was an abrupt transition, simulated by an instantaneous increase in precipitation to the threshold (TS) amount required to force paleo-lake Chew Bahir to the overflow sill. However, this only represents the minimum precipitation required to fill Paleo-lake Chew Bahir to the overflow level, therefore we additionally considered two scenarios, in which the threshold could have been exceeded (S2: TS+5\%, S3: 
TS $+10 \%)$. We simulated a gradual increase in precipitation from modern day conditions to TS over 50,100, 250, and 500 years. The termination of the AHP was also simulated, where the abrupt scenario saw an immediate transition from increased precipitation rates (TS) to modern day precipitation. The gradual offset was simulated by decreasing the precipitation amount linearly from TS to the modern day amount within 50, 100, 250, and 500 years.

\section{Amplifier Lake Characteristics}

In order to compare the basins of Lake Abaya, Lake Chamo and paleo-lake Chew Bahir with other lakes within the EARS, we calculated the hypsometric integral (HI; Pike and Wilson, 1971) following Equation (10).

$$
H I=\frac{\text { mean elevation }- \text { minimum elevation }}{\text { maximum elevation }- \text { minimum elevation }}
$$

We calculated the $A I$ of each, individual catchment as the quotient precipitation $\left(\mathrm{mm} \mathrm{a}^{-1}\right)$ and potential evaporation $(\mathrm{mm}$ $\mathrm{a}^{-1}$, Thornthwaite, 1948) within each catchment. The term amplifier lake characterizes lakes in the EARS that react very sensitively to even moderate climate changes (Street-Perrott, 1985; Olaka et al., 2010; Trauth et al., 2010). We compared the $\mathrm{HI}$ and AI of paleo-lake Chew Bahir, lakes Abaya, and Chamo with other lake basins and classified amplifier lakes in the EARS based on Olaka et al. (2010).

\section{Chew Bahir Lake Level Reconstruction}

To translate changes indicated by climate proxies in the Chew Bahir drill core sediments into actual lake level changes, we used the established aridity proxy potassium (K) (Foerster et al., 2012, 2015, 2018; Trauth et al., 2018). High K concentrations in the sedimentary record have been documented to be strongly controlled by the hydrochemistry of the paleo-lake and porewaters. Such changes in salinity and alkalinity are typically caused by a drier climate and associated lake water evaporation (Foerster et al., 2018). For our study, we are using the most complete and high resolution record from Chew Bahir for the last $20 \mathrm{ka}$ BP, a composite of pilot core CB- 01 and CB- 03 , as discussed in Foerster et al. (2015). In our study, we compare the timing of K-changes with modeled response times of paleolake Chew Bahir's lake level, and interpret whether long-term and short-term fluctuations can be explained by abrupt or gradual changes in precipitation based on their duration and also K content.

\section{RESULTS}

\section{DEM Analysis Overflow Regime}

As summarized in Table 3, an additional $25.2 \mathrm{~km}^{3}$ of water would be required to initiate drainage at the overflow sill from Lake Abaya toward Lake Chamo, resulting in an increased lake surface area of $3.6 \%$. To initiate overflow from Lake Chamo toward Chew Bahir, only an additional $5.2 \mathrm{~km}^{3}$ is required, which would increase the lake area by $5 \%$. Paleo-lake Chew Bahir would require $83.2 \mathrm{~km}^{3}$ for the lake level to reach the overflow sill and initiate drainage into Lake Turkana. In this
TABLE 3 | Summary of major output parameters.

\begin{tabular}{|c|c|c|c|c|}
\hline Parameter & Unit & Chew Bahir & Chamo & Abaya \\
\hline \multicolumn{5}{|c|}{ DIGITAL ELEVATION MODEL ANALYSIS } \\
\hline Catchment size & $\mathrm{km}^{2}$ & 20,650 & 1,793 & 16,203 \\
\hline Modern day lake level & m a.s.l. & 498 & 1,109 & 1,176 \\
\hline Maximum lake level & m a.s.l. & 543 & 1,123 & 1,194 \\
\hline Modern day lake area & $\mathrm{km}^{2}$ & 0 & 310 & 1,081 \\
\hline Maximum lake area & $\mathrm{km}^{2}$ & 2,486 & 394 & 1,557 \\
\hline Additional lake volume & $\mathrm{km}^{3}$ & 83 & 5 & 25 \\
\hline $\begin{array}{l}\text { Modern day lake area } \\
\text { ratio, } \alpha_{w}\end{array}$ & $\%$ & 0 & 17 & 6 \\
\hline $\begin{array}{l}\text { Maximum lake area } \\
\text { ratio, } \alpha_{w}\end{array}$ & $\%$ & 12 & 22 & 9.6 \\
\hline Hypsometric Integral & & 0.23 & 0.15 & 0.25 \\
\hline Aridity Index & & 0.83 & 1.33 & 1.72 \\
\hline \multicolumn{5}{|c|}{ LAKE BALANCE MODEL } \\
\hline $\begin{array}{l}\text { Precipitation modern, } \\
\text { Pbas (rate, volume) }\end{array}$ & $\left(\mathrm{mm} \mathrm{a}^{-1}, \mathrm{~km}^{3}\right)$ & $917,18.9$ & $1,211,2.2$ & $1,407,22.8$ \\
\hline $\begin{array}{l}\text { Precipitation paleo } \\
20-30 \% \text { increased, } \\
\text { Pbas (rate) }\end{array}$ & $\left(\mathrm{mm} \mathrm{a}^{-1}\right)$ & $1,100-1,192$ & $1,453-1,574$ & $1,688-1,829$ \\
\hline $\begin{array}{l}\text { Groundwater, Sbas } \\
\text { (rate, volume) }\end{array}$ & $\left(\mathrm{mm} \mathrm{a}^{-1}, \mathrm{~km}^{3}\right)$ & $24,0.5$ & $80,0.1$ & $260,4.2$ \\
\hline $\begin{array}{l}\text { Evaporation on land, } \mathrm{E}_{\mathrm{l}} \\
\text { (rate, volume) }\end{array}$ & $\left(\mathrm{mm} \mathrm{a}^{-1}, \mathrm{~km}^{3}\right)$ & $892,18.4$ & $1,060,1.6$ & $1,123,17$ \\
\hline $\begin{array}{l}\text { Evaporation on water, } \\
E_{w} \text { (rate, volume) }\end{array}$ & $\left(\mathrm{mm} \mathrm{a}^{-1}, \mathrm{~km}^{3}\right)$ & $1,908,0$ & $1,550,0.5$ & $1,513,1.6$ \\
\hline
\end{tabular}

scenario, paleo-lake Chew Bahir would cover $12 \%$ of the total catchment area.

\section{Lake Balance Model Results}

Sensitivity tests of the major environmental parameters in the LBM including temperature, cloud cover, humidity and wind speed were calculated for the paleo-lake Chew Bahir catchment (Figure 3). For example, a modeled mean temperature rise of $1^{\circ} \mathrm{C}$ with an error below $1^{\circ} \mathrm{C}$ (New et al., 2002) would result in an increase of $4.7 \%\left(42 \mathrm{~mm} \mathrm{a}^{-1}\right)$ in $\mathrm{ET}_{\mathrm{a}}$ for the average land evaporation in the paleo-lake Chew Bahir catchment (Figure 3A). Cloud cover measurements from MODIS typically have an error below 5\% (Platnick et al., 2015). An increase in average cloud cover by $5 \%$ would decrease $\mathrm{ET}_{\mathrm{a}}$ by $\sim 4 \%(367 \mathrm{~mm}$ $\mathrm{a}^{-1}$, Figure 3B). The dataset of the relative humidity shows errors up to $\pm 15 \%$ (New et al., 2002). Hence, an increase in the average relative humidity of $15 \%$ would decrease $\mathrm{ET}_{\mathrm{a}}$ on land by $8.7 \%$ $\left(78 \mathrm{~mm} \mathrm{a}^{-1}\right.$, Figure $\left.3 \mathrm{C}\right)$. The windspeed dataset has the highest errors and according to New et al. (2002) the maximum deviation for specific measures sites in eastern Africa ranges between 40 and $60 \%$. For example, an increase in wind speed of $1 \mathrm{~m} \mathrm{~s}^{-1}$ (corresponding to a $45 \%$ deviation) would enhance $\mathrm{ET}_{\mathrm{a}}$ by $19.5 \%$ $\left(174 \mathrm{~mm} \mathrm{a}^{-1}\right.$, Figure 3C).

\section{SEBAL Results}

Using 43 days with a clear sky of the reference year, the calculated mean $R_{n}$ was $459 \mathrm{~W} \mathrm{~m}^{-2}\left(\sigma=54 \mathrm{~W} \mathrm{~m}^{-2}\right)$, the average $G$ was $75 \mathrm{~W} \mathrm{~m}^{-2}\left(\sigma=8.6 \mathrm{~W} \mathrm{~m}^{-2}\right)$, and $H$ was $130 \mathrm{~W} \mathrm{~m}^{-2}(\sigma$ 


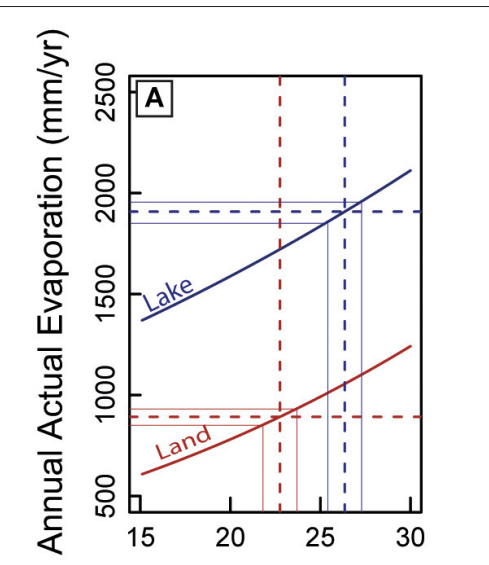

Air Temperature $\left({ }^{\circ} \mathrm{C}\right)$



Cloud Cover (\%)
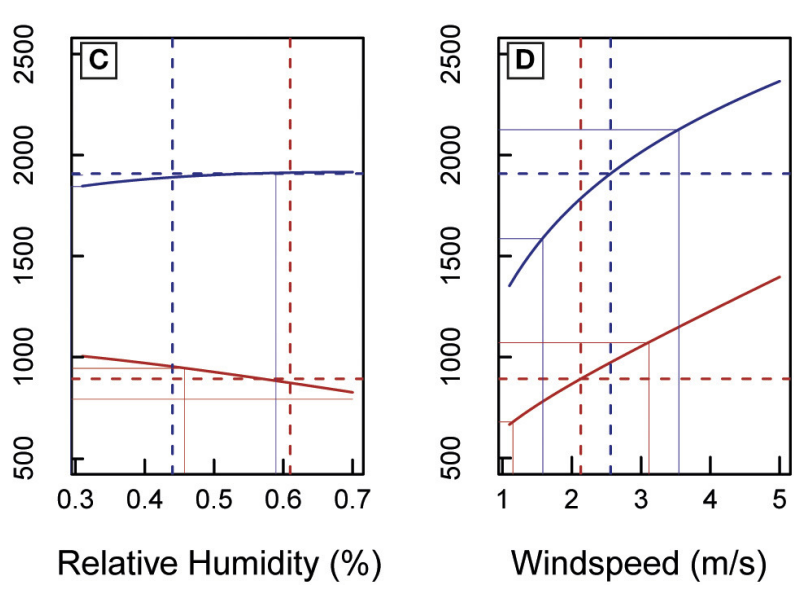

FIGURE 3 | The effects of environmental parameters on lake and land evaporation for the Chew Bahir basin: (A) air temperature, (B) cloud cover, (C) relative humidity, and (D) windspeed. Dashed lines indicate used input parameter and resulting annual actual evaporation of the LBM. Solid thin lines indicate maximum/minimum errors with resulting maxima/minima of the annual actual evaporation.

$\left.=27.3 \mathrm{~W} \mathrm{~m}^{-2}\right)$. Those fluxes result in $\Delta$ of $0.64(\sigma=0.074)$ and $\lambda E$ of $0.38 \mathrm{~mm} \mathrm{~h}^{-1}(\sigma=0.07) . R N_{24}$ was $137 \mathrm{~W} \mathrm{~m}^{-2}(\sigma$ $\left.=7.07 \mathrm{~W} \mathrm{~m} \mathrm{~m}^{-2}\right)$, resulting in $E T_{24}$ of $3.18 \mathrm{~mm} \mathrm{~d}^{-1}(\sigma=0.33$ $\left.\mathrm{mm} \mathrm{d}^{-1}\right)$.

The annual water balance shows a bimodal precipitation $\left(916 \mathrm{~mm} \mathrm{a}^{-1}\right)$ and $E T_{a}\left(847 \mathrm{~mm} \mathrm{a}^{-1}\right)$ and an unimodal $E T_{p}$ (see Figure 4B). The spatial distribution (see Figure 4A) of $E T_{a}$ ranges from 52 to $1,360 \mathrm{~mm} \mathrm{a}^{-1}$. The southern part of the catchment has the lowest values, whereas the northern and elevated rift shoulders, with streams and adjacent wetlands, has the highest $\mathrm{ET}_{\mathrm{a}}$ due to greater water availability.

\section{Evaporation Estimate Comparison}

Using the SEBAL approach, $E T_{a}$ was $847 \mathrm{~mm} \mathrm{a}^{-1}$ for the paleolake Chew Bahir catchment, compared to $892 \mathrm{~mm} \mathrm{a}^{-1}$ using the bulk transfer method, which is a relative difference of $5 \%(45 \mathrm{~mm}$ $\mathrm{a}^{-1}$ ). This leads to a shift in the closed water balance of the paleolake Chew Bahir catchment and a difference in the estimated catchment-wide groundwater recharge rates between $69 \mathrm{~mm} \mathrm{a}^{-1}$ (SEBAL) and $24 \mathrm{~mm} \mathrm{a}^{-1}$ (LBM). We calculated annual lake evaporation for Lake Abaya of $1,513 \mathrm{~mm}$ and for Lake Chamo of $1,550 \mathrm{~mm} \mathrm{a}^{-1}$ using the bulk transfer Lake Balance Model. At the Arba Minch metrological station $\left(6^{\circ} 2^{\prime} \mathrm{N}, 37^{\circ} 33^{\prime} \mathrm{E}\right)$, class A pan evaporation was measured from 1985 to $2005 \mathrm{AD}$, with an average of $2,191 \mathrm{~mm} \mathrm{a}^{-1}$. This results, with a correction factor of 0.85 , in a 20 -years average annual lake evaporation of $1,862 \mathrm{~mm}$ $\mathrm{a}^{-1}$ as calculated by Belete (2009). These values differ from our model results by 16.7 to $18.7 \%$, which could be related to a high uncertainty of the individually determined correction factor for pan evaporation data.

\section{Combined Lake Balance Model and Paleo-Water Balances Results Modeling Increased Precipitation Scenarios}

The transition of paleo-lake Chew Bahir from "no lake" to "overflow conditions" at a lake surface level of $543 \mathrm{~m}$ a.s.l., $45 \mathrm{~m}$ above basin floor, was simulated over a period of 500 years. The transition occurs at a minimum precipitation increase at a TS of $6.5 \%$ compared to modern day 12-years TRMM average and occurs within 302 years (Figure $\mathbf{5 A}$ ). The transition time required to go from "no lake" to "overflow conditions" decreases with increasing precipitation to, for example, 39 years (TS $+5 \%=$ $11.5 \%$ ) and 21 years (TS+10\% $=16.5 \%$ ), as indicated by stars in Figure 5A.

The water flux from one basin to the next basin increases linearly as soon as the overflow threshold of each basin is reached (Figure 5B). For example, the water flux from Lake Chamo to paleo-lake Chew Bahir increases starting from zero when precipitation is enhanced by $1.1 \%$, and rises up to $3.9 \mathrm{~km}^{3} \mathrm{a}^{-1}$ when precipitation is $16.5 \%$ higher than today.

The calculated inflow ratio for paleo-lake Chew Bahir describes the ratio between the annual water derived by precipitation within the catchment and the inflow from Lake Chamo (Figure 5C). The inflow ratio quantifies the high importance of the extended catchment of Lake Abaya and Lake Chamo for the water balance of paleo-lake Chew Bahir. The inflow ratio of Chew Bahir increases starting from 0 to $1.1 \%$ enhanced precipitation and reaches $6.3 \%$ when precipitation enhances to the threshold precipitation ( $\mathrm{TS}=6.5 \%$ ) for overflow conditions.

\section{Seasonality Changes Results}

The difference in annual evaporation on land of $167.6 \mathrm{~mm}$ for the paleo-lake Chew Bahir catchment that we assessed needs to be considered to compensate for the additional rainy months from June to September according to the SEBAL processing. This difference in annual evaporation on land results in an increased threshold to achieve the transition from "no lake" to "overflow conditions." When considering a third rainy season to have been active during the AHP, the threshold precipitation to fill paleolake Chew Bahir up to its overflow level would have increased 


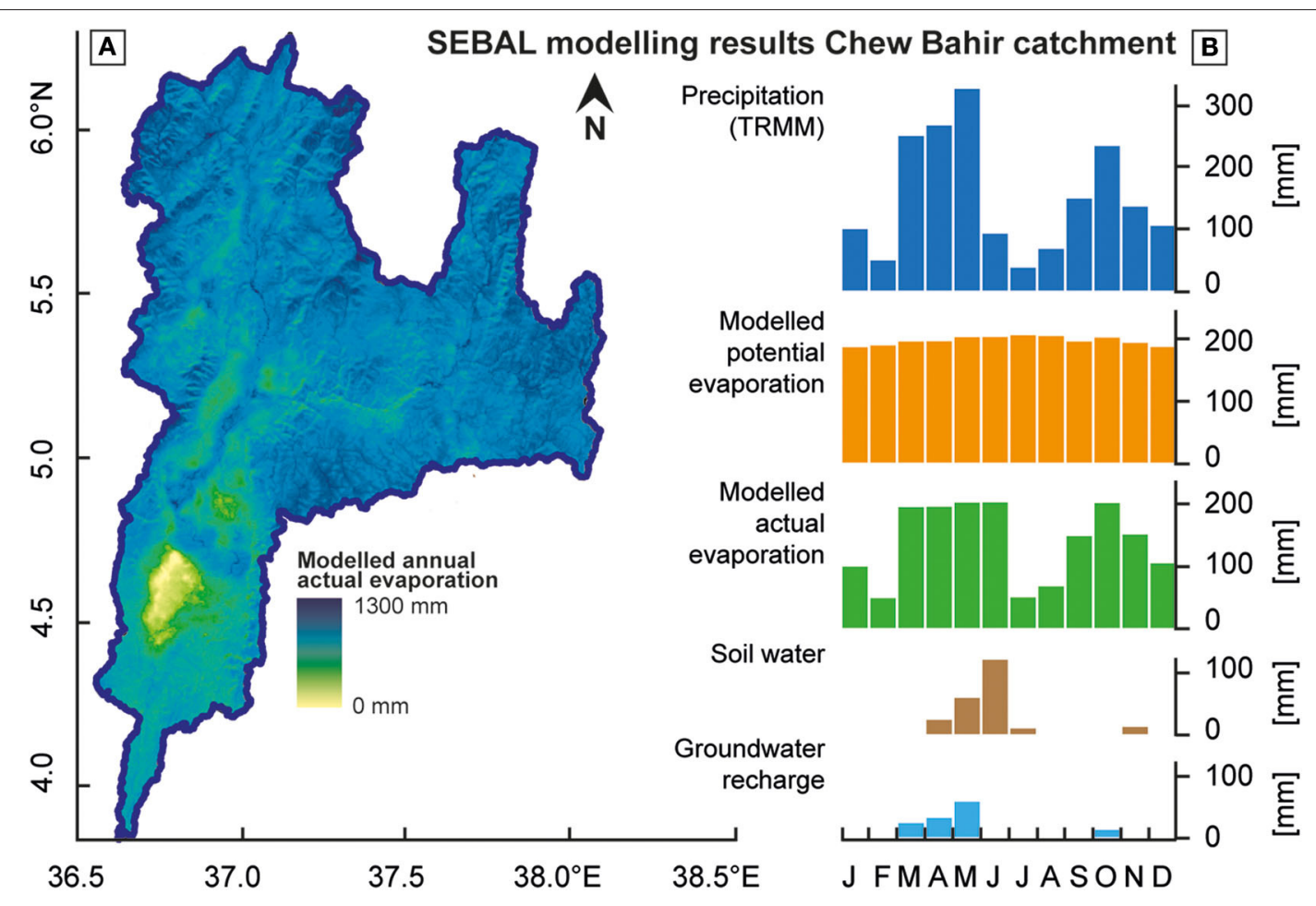

FIGURE 4 | SEBAL results for paleo-lake Chew Bahir catchment: (A) Map of actual evaporation distribution throughout the catchment. (B) Monthly precipitation and monthly water balance of the Chew Bahir catchment.
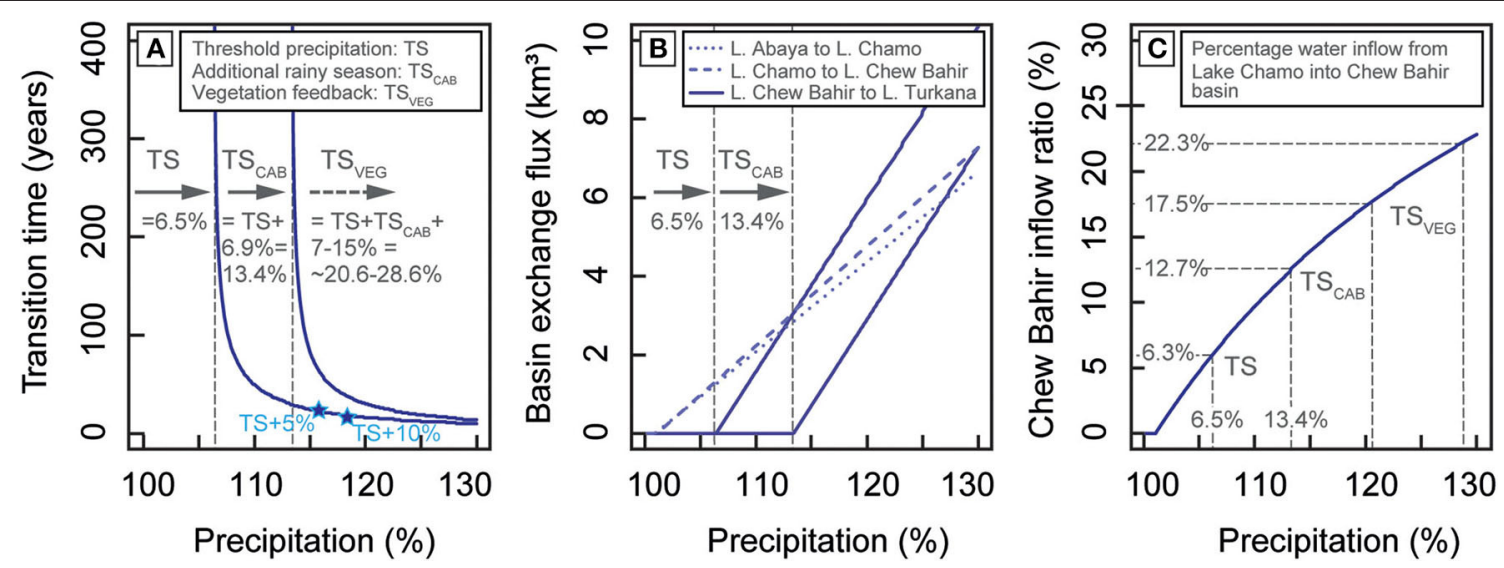

FIGURE 5 | The effects of precipitation increase on the investigated lake basins: (A) Transition times of paleo-lake Chew Bahir from "no lake" to "overflowing lake" into Lake Turkana under minimum threshold (TS) conditions where seasonality has not changed; under the consideration of an additional rainy season caused by a shift of the location of the Congo Air Boundary (TS $\mathrm{CAB}_{\text {) }}$; and the incorporation of theoretically vegetation feedback (TSVEG) with values taken from Bergner et al. (2003), since no local paleo-data are available. The graph shows the increasing pace of lake level rise with increasing precipitation. (B) Water mass exchange between the three investigated basins for the scenarios, TS and TS $\mathrm{CAB}_{\text {. }}$ (C) Precipitation and overflowing Lake Chamo-Abaya as relative water sources of paleo-lake Chew Bahir showing the importance of an enlarged catchment of Chew Bahir during overflow times of all lakes. Whereas, under TS conditions Chew Bahir inflow ratio is at $6.3 \%$, the inflow doubles up to $12.7 \%$ when considering an additional rainy season.

by $6.9 \%\left(\mathrm{TS}_{\mathrm{CAB}}=\mathrm{TS}+6.9 \%=13.4 \%\right)$ compared to the modern day precipitation amount (Figures $\mathbf{5 A}, \mathbf{C}$ ). The consideration of a changing vegetation on the evaporation and the resulting necessity of an increased precipitation is $7-15 \%$, as suggested by Bergner et al. (2003). This leads to a combined threshold $\mathrm{TS}_{\mathrm{VEG}}$ of 20.6 to $28.6 \%$ ( $^{\mathrm{T}} \mathrm{VEG}_{\mathrm{VE}}=\mathrm{TS}+\mathrm{TS}_{\mathrm{CAB}}+7-15 \%=20.6-$ $28.6 \% ; 20-30 \%$ rounded) compared to the modern day annual precipitation (Figures 5A,C). 


\section{AHP Transition Times Results}

For abrupt "lake fill" scenarios (Figure 6A), the lake filling curve using the minimum precipitation amount of $13.4 \%$ (TS $_{\mathrm{CAB}}$ ) required to fill paleo-lake Chew Bahir up its overflow sill, leads to a slow, around 300 years, asymptotic reaction of the lake surface level over time as soon as paleo-lake Chew Bahir derives a constant water flux from Lake Chamo. Whereas, an increase of the precipitation amount for example by $5 \%$ $\left(\mathrm{TS}_{\mathrm{CAB}}+5 \%\right)$ or $10 \%\left(\mathrm{TS}_{\mathrm{CAB}}+10 \%\right)$ above the threshold $\left(\mathrm{TS}_{\mathrm{CAB}}\right)$ leads to a fast transition of paleo-lake Chew Bahir from "no lake" to "overflow conditions" within 30 and 22 years, respectively. Lake Abaya and Lake Chamo, however, are showing for all simulated precipitation signals decadal to sub-decadal transition times.

For gradual "lake fill" scenarios (Figure 6B) within 50, 100, 250 , and 500 years from the modern day precipitation amount to the threshold, the same asymptotic lake surface level reaction pattern in time is identified, but it is delayed through the gradual precipitation signal. This gradual delay factor leads to corresponding centennial transition (>350 years) times. Lake Abaya and Lake Chamo show for all simulated gradual "lake fill" scenarios filling times between $40-160$ and 50-180 years, respectively.

We simulated abrupt "lake drain" scenarios (Figure 6C) starting with lakes at their specific overflow sill: Lake Abaya at $+18 \mathrm{~m}$, Lake Chamo at $+14 \mathrm{~m}$, and paleo-lake Chew Bahir at $+45 \mathrm{~m}$ above the modern day lake surface levels. For this scenario paleo-lake Chew Bahir would have been dried out within 45 years, whereas Lake Chamo and Lake Abaya would need more than 100 years to reach their new equilibrium state.

The simulation of gradual "lake drain" scenarios within 50, 100,250 , or 500 years to modern day conditions leads to delayed transition times of paleo-lake Chew Bahir from 70 up to 370 years before drying up (Figure 6D). Under gradual precipitation decrease Lake Abaya dries up between 170 and $>500$ years, and Lake Chamo takes the longest with 370 to $>500$ years.

\section{Amplifier Lake Characteristic Results}

Following the main principles for amplifier lake characterization (HI 0.23-0.3; Olaka et al., 2010; Figure 7), Chew Bahir (HI: 0.23, AI: 0.83) and Abaya (HI: 0.25, AI: 1.72) can be characterized as amplifier lakes. Chew Bahir is with an $\mathrm{AI}<1$ characterized as a


FIGURE 6 | Modeled pace of lake transitions under abrupt and gradual precipitation changes: (A) Abrupt increase in precipitation from modern values to TS ${ }_{C A B}$ values (13.4\%) as a minimum possible amount of rainfall to fill up the investigated lake basins. TS $\mathrm{CAB}+5 \%$ and $\mathrm{TS}_{\mathrm{CAB}}+10 \%$ are provided as examples for even higher precipitation that was provided during the AHP, for example. (B) Lake fill scenario under gradual increase in precipitation from modern values to TS over 50, 100, 250, and 500 years. (C) Abrupt decrease in precipitation from TS $\mathrm{CAB}_{\mathrm{B}}$ to modern values. (D) Lake regression scenario under gradual decrease in precipitation from $\mathrm{TS}_{\mathrm{CAB}}$ to modern values over $50,100,250$, and 500 years. 




FIGURE 7 | The characterization of amplifier lakes: Hypsometric integral (HI) and Aridity Index (Al) of major lake basins within the EARS as published by Olaka et al. (2010) including new calculated values of paleo-lake Chew Bahir, Lake Abaya, and Lake Chamo (in yellow) from this study. Amplification of precipitation changes occurs in lakes with $\mathrm{HI}$ of 0.23-0.3 according to Olaka et al. (2010). We postulate that Al has changed in the course of climatic changes and thus amplification influences, such as groundwater and precipitation.

lake with slightly higher potential evaporation than precipitation, whereas Abaya is the wettest of all investigated basins with $\mathrm{AI}>1$ (Figure 7). Lake Chamo (HI: 0.15, AI: 1.33) cannot be considered as an amplifier lake.

\section{DISCUSSION}

\section{Advantages and Limitation of the LBM Paleo-Precipitation Estimates}

The results from the hydro-balance modeling show that a surplus in precipitation of $20-30 \%$ compared to present day values is required to fill the presently dry paleo-lake Chew Bahir to its overflow sill at $545 \mathrm{~m}$ a.s.l. and a depth of $\sim 45 \mathrm{~m}$, resulting in a $\sim 2,500 \mathrm{~km}^{2}$ large freshwater lake. These final estimates are the result of three different assumptions: (1) TS of $+6.5 \%$ accounts for the minimum precipitation required to fill paleo-lake Chew Bahir to its overflow level (classical hydro-balance approach), (2) $\mathrm{TS}_{\mathrm{CAB}}$ equals the sum of TS $+6.9 \%$ to include extra precipitation outside the current rainy season from the theoretical shift of the $\mathrm{CAB}$ over the rift region during the AHP as suggested by previous studies (e.g., Junginger, 2011; Costa et al., 2014; Junginger et al., 2014; Bloszies et al., 2015; Beck et al., 2019), and (3) TS the sum $\mathrm{TS}+\mathrm{TS}_{\mathrm{CAB}}+7-15 \%$ precipitation to include the impact of vegetation feedback (Figure 5). Vegetation feedback, which increases transpiration and thus precipitation was approximated in our model, based on biosphere-feedback modeling results (7$15 \%$; Bergner et al., 2003) from the nearby Lake Naivasha basin in the central Kenya rift, due to a lack of direct paleo-vegetation data. Numerous studies from eastern Africa strongly suggest a pronounced vegetation change between the AHP and today (e.g., Lamb et al., 2004; Vincens et al., 2005; Umer et al., 2007; Rucina et al., 2009; Marchant et al., 2018) and that vegetation feedback played an important role in precipitation (e.g., Claussen et al., 2017). However, local and regional information during the AHP (e.g., pollen, non-pollen palynomorphs, charcoal or phytoliths from sediments) are currently lacking and would help refine estimates of paleo-precipitation changes due to vegetation feedback, allowing for improved estimations of past hydrological budgets in southern Ethiopia.

Our modeling results of precipitation increase (20-30\%) for paleo-lake Chew Bahir are of the same order of magnitude as results for similar studies within the EARS during the AHP (Figure 1), such as Ziway-Shala (+28\%, Gillespie et al., 1983), Lake Turkana (+20\%, Hastenrath and Kutzbach, 1983), Suguta Valley (+26\%, Junginger and Trauth, 2013), Lake NakuruElmenteita (+23-45\%\%, Dühnforth et al., 2006; Kniess, 2006), and Lake Naivasha (+29-33\%, Hastenrath and Kutzbach, 1983; Bergner et al., 2003). However, almost all results stem from different modeling approaches. None of the previous models have considered hydrological connectivity or the impact on evaporation $\left(\mathrm{ET}_{\mathrm{a}}\right)$ due to a third rainy season. The latter would have had especially affected the catchments of Lake Turkana, Lake Nakuru-Elementeita, Lake Naivasha and paleo-Lake Suguta, as they most likely experienced a precipitation increase due to the 
change in the position of the $\mathrm{CAB}$ during the AHP (Junginger et al., 2014). We therefore propose that lake catchments and LBM results in the EARS under the potential influence of the $\mathrm{CAB}$ during the AHP would require additional increased precipitation.

Another important aspect in hydrological modeling of eastern African rift lakes is the inclusion of basin surface connectivity in major humid periods (Figure 1). Paleo-lake Chew Bahir received $15-25 \%$ of its additional water during the AHP from overflowing lakes Abaya and Chamo via the Segan River. Such hydrological connectivity during the AHP almost doubled the catchment size of Chew Bahir from 20,650 to $38,647 \mathrm{~km}^{2}$ (Figure 2). However, hydrological basin connectivity was likely intermittent, only occurring during strong humid phases (Figure 8). Intermittent connectivity during high-stands could have been caused by short-term abrupt changes in the position of the $C A B$ and associated temporal cut offs from the surplus of water. Such intermittent surficial hydrological connectivity is likely relevant for all EARS lakes in the mid and lower altitudes, such as lakes Abhé, Turkana, Suguta, Baringo-Bogoria, Magadi, and Manyara (Figure 1E).

The water balance has varied due to increased precipitation and changes in other environmental parameters (e.g., as mentioned in Table 1) which influence the inflows and outflows into the basin. It is difficult to quantify these parameters (e.g., cloud cover, wind speed, and relative humidity) during the AHP. Proxy record reconstructions over the AHP however, can provide some insights. The GDGT based temperature reconstruction for eastern Africa by Loomis et al. (2012) reveals a colder climate at the beginning of the AHP at around $15 \mathrm{ka} \mathrm{BP}$ and a climate which was up to $3^{\circ} \mathrm{C}$ between 12 and $5 \mathrm{ka}$ BP. Based on our sensitivity analysis for environmental parameters (section Lake Balance Model), an increase of around three Kelvin could increase the actual evaporation by up to $14 \%$. A decrease in temperature of three Kelvin could lower the evaporation by the same amount. In terms of the resulting precipitation estimates, the early AHP with a slightly colder climate would need a slightly lower precipitation amount to reach a positive water budget, whereas the late phase of the AHP would need a slight higher precipitation amount to reach a positive water budget.

In summary, our study reveals the same magnitude of precipitation increase $(+20-30 \%$ of modern day) in eastern Africa for the AHP as most other studies, but separates this threshold into parts. Those parts would need to be added (precipitation during modern day dry months) or subtracted (paleo hydrological connectivity) for other lake basins within the EARS, but can only be quantified in a site specific manner.

\section{Evaporation Estimates Discussion}

We compensated the lack of ground measured climate data by using remote sensing MODIS products, modeled climate data and calculated the actual evaporation additionally through SEBAL. This algorithm as proposed by Bastiaanssen et al. (1998a,b) has been applied in numerous variations depending on the data, landscapes and research designs. Studies showed inaccuracy of SEBAL at a field-scale and suggested to use METRIC or SEBS instead (e.g., Losgedaragh and Rahimzadegan,
2018). Mkhwanazi et al. (2015) implemented advective conditions within the SEBAL for crop evaporation studies on a field-scale, because the algorithm underestimate actual evaporation with a mean bias Error of $17.1 \%$. SEBAL for catchment-scale studies instead showed an accuracy above 95\% (Bastiaanssen et al., 2005). A 3 years SEBAL application in Tanzania and Kenya with a comparable research design as our application achieved a difference between the SEBAL results and the water balance of the catchment of $12 \%$. For a SEBAL application in the Suguta Valley the SEBAL $E T_{a}$ is $5 \%$ lower than the bulk transfer calculated $E T_{a}$ of the LBM (Borchardt and Trauth, 2012; Junginger and Trauth, 2013).

The evaporation estimates of the SEBAL, the bulk-transfer formula and the pan-evaporation measurement have been compared and vary between 5 and $18.7 \%$. This means the input water fluxes for the LBM could vary at the same magnitude. But those fluxes are not independent, instead the modern day water budget for each year is in balance. An increase in $E T_{a}$ on land would necessarily imply, $E T_{a}$ on water or the groundwater recharge rate is overestimated. The same yields for the sensitivity analysis of the bulk-transfer derived $E T_{a}$. The variation of the evaporation rate depending on the environmental parameters shows possible inter-annual variability and possible microclimate caused differences within the catchment. This spatial variety is mapped by SEBAL. However, besides the sensitivity, spatial variety and inter-annual variability, the accuracy of each multi-annual average water flux rate is due to the multi-method verification and the closed water balance of each catchment with an definite error below $20 \%$. The different subdivisions of precipitation within each catchment between $E T_{a}$ on water and land affects the paleo-precipitation threshold in approximately one-tenth of the maximum deviation between $E T_{a}$ on water and land. This leads to a robust error of the threshold of $2 \%$ and an overall paleo-precipitation threshold for paleo-lake Chew Bahir of plus $20-30 \%$ precipitation in a multi-annual average compared to the modern day conditions.

\section{Subsurface Flows Discussion}

Endorheic basins, and their subsequent lakes, can be classified into three groups; (1) flow-through lakes, (2) discharge lakes, and (3) recharge lakes (e.g., Olaka, 2011 and references therein). Flow-through lakes are balanced $\left(S_{\text {bas }}=0\right)$. Discharge lakes are positively affected by groundwater flowing into the lake $\left(S_{b a s}>\right.$ $0)$ and recharge lakes lake water seeps into the groundwater $\left(S_{b a s}\right.$ $<0$ ). During the AHP, when the overall moisture availability in the atmosphere was much higher and lake levels rose, changes in the groundwater levels may have changed the classification and status of the basin. Changes in groundwater inflows and outflows, would have subsequent impacts on the overall lake water balance. For example, groundwater discharge into lake basins could reduce their sensitivity to reduced precipitation input in shortterm dry periods and potentially delay lake desiccation in protracted dry phases. This is a possible mechanism to explain why extremely arid catchments, such as paleo-Lake Suguta or Lake Nakuru-Elementeita, developed and maintained paleolakes which were $10-300 \mathrm{~m}$ deeper than today (Olaka et al., 




FIGURE 8 | Chew Bahir LBM-based paleo-lake level reconstruction and comparison to adjacent lakes: (A) CB01 K proxy-record by Foerster et al. (2015) with dry events discussed in the text and transition modes. (B) Reconstructed lake level curve of Chew Bahir based on the lake-balance model (LBM) applied to changes in the $\mathrm{K}$ concentration of $\mathrm{CBO1}$. (C) Human occupation history of the Ethiopian highlands implies enhanced activities when lakes in the lower elevated rift basins, such as paleo-lake Chew Bahir became to saline or even dried up. The Ethiopian highlands may thus have been a refuge area during unfavorable times as Foerster et al. (2015) suggested. Cow indicates cultural transition from fishing/hunting/gathering to herding in the Ethiopian Highlands. (D) Lake level reconstruction of Suguta Valley (Junginger et al., 2014) as the mirror basin of Chew Bahir. (E) Lake level reconstruction of Lake Turkana by Garcin et al. (2012) and Beck et al. (2019) (blue, shaded curve), and by Bloszies et al. (2015) (green). (F) Strontium isotopes measured on aquatic fossils from lake Turkana sediments (van der Lubbe et al., 2017). 
2010). For example, Olaka (2011) estimated response times of 2-2.7 ka for groundwater to drain a $41 \mathrm{~km}^{3}$ large aquifer underneath the Eburro volcano complex located between Lake Naivasha and Lake Nakuru in the central Kenya Rift (Figure 1). Unfortunately, the southern MER lack this kind of information, despite preliminary evidence of significant groundwater aquifers in the central part of the Ethiopian rift (Kebede and Travi, 2012).

In terms of the groundwater recharge rate and the subsequent effect on the paleo-precipitation threshold for the African Humid Period, we parameterised the groundwater recharge rate as the surplus of the water balance budget, which is in contrast to previous LBM studies (see section Lake Balance of Lakes Abaya, Chamo, and Paleo-Lake Chew Bahir). Based on Chernet (1993) recharge rates between 50 and $150 \mathrm{~mm} \mathrm{a}^{-1}$ are typical, which would be $\sim 5-15 \%$ of the annual precipitation within the Chew Bahir catchment. We calculated a groundwater recharge rate of $24 \mathrm{~mm} \mathrm{a}^{-1}$ using the LBM and $69 \mathrm{~mm} \mathrm{a}^{-1}$ using SEBAL. These comparisons show the possible errors of our modeling results due to this uncertainty, which are a quantity smaller than the annual fluxes in precipitation and evaporation (Dühnforth et al., 2006).

\section{Lake Response Times Discussion Amplifier Lake Characteristics}

Olaka et al. (2010) postulated that amplifier lakes, where AI $<1$ $\left(\mathrm{ET}_{\mathrm{p}}>\mathrm{P}\right)$, likely received greater groundwater or surface inputs during the AHP, in order to maintain expansive lake systems in semiarid to arid regions in the EARS. In contrast, lakes with $\mathrm{AI}>1\left(\mathrm{ET}_{\mathrm{p}}<\mathrm{P}\right)$, which are prevalent on the high plateaus of the rift margins and Ethiopian Domes (Figure 1), are and were during the AHP amplified through precipitation. However, these calculations are based on present day conditions and may be irrelevant in a paleo context where $P$ and $E T_{p}$ would have been vastly different, and consequently the AI. We expect in a paleo context, that the position of the AI for the respective paleo lakes would likely shift vertically along the y-axes of Figure 7 over time periods of 10-10,000 years. Based on our LBM, for example, the rate of groundwater feeding paleo-lake Chew Bahir today remains smaller than the rate of groundwater discharge within the catchment and is furthermore a magnitude smaller than the water mass exchange rates due to precipitation, evaporation and surface basin connectivity. However, the groundwater system could act as a millennial-scale buffer, which is recharged during major humid periods may slow the transition to lake desiccation in drier periods (e.g., Garcin et al., 2009; Olaka, 2011).

Although Lake Chamo is not characterized as an amplifier lake, it can receive additional surface inflows from Lake Abaya, due to the very shallow overflow between the two lakes (Figures 1, 2). Due to the extremely shallow overflow sill of Lake Abaya toward Lake Chamo and toward paleo-lake Chew Bahir, we hypothesize that even sub-decadal precipitation shifts may have triggered overflow to the paleo-lake Chew Bahir basin, and thus would have caused abrupt changes in the water budget of paleo-lake Chew Bahir. It is therefore highly likely that paleolake Chew Bahir was able to change during the AHP from a fresh-water lake to a desert within only a couple of decades. Such sensitivity to even moderate climate changes makes the paleo-lake Chew Bahir basin responsive to even sub-decadal climate fluctuations in contrast to, for example the Suguta Valley, which has a greater buffering capacity to short-term variability in precipitation, due to its larger size and depth of the paleo-lake (paleo-lake depth of $295 \mathrm{~m}$ ), and higher overflow sill (Figures 1, 8).

We understand paleo-lake Chew Bahir as a double amplifier lake, pronouncing the unique and high sensitivity of the landscape and lakes water-level reaction to precipitation signals. This is due to (1) the classification of its catchment as an amplifier lake (Figure 1) and (2) the importance of the catchment of lakes Chamo and Abaya for the paleo water balance of paleo-lake Chew Bahir. This expansion of paleo-lake Chew Bahirs catchment in case of over-spilling lakes Abaya and Chamo into the Chew Bahir basin amplifies the lakes reaction to precipitation changes and causes rapid filling if there is a significant water drain, or rapid draining if this hydrological connectivity gets cut off.

\section{Pace and Magnitude of Lake Level Changes}

In a previous study by Trauth et al. (2018) a change point analysis was applied to the aridity proxy K-record by Foerster et al. (2012, 2015) to investigate the timing and duration of climatic changes. Our study now is able to add the character and magnitude of lake level changes and thus allows to infer direct implications to biosphere impacts.

Trauth et al. (2018) stated that the most dramatic changes occurred during the onset of the AHP and the interruption by the Younger Dryas (YD), a global cold event, known as a pronounced dry episode in eastern Africa (e.g., Barker et al., 2004). The onset of the AHP in the Chew Bahir basin, so Trauth et al. (2018), occurred within $\sim 240$ years (15.7-15.46 ka BP). Within such period of time, paleo-lake Chew Bahir would have been able to reach the overflow sill toward Lake Turkana (Figures 1, 8). The extreme arid interval in Chew Bahir between 13.2 and $11.73 \mathrm{ka}$ BP, largely coinciding with the YD chronozone, shows abrupt changes in the K- record. Those were presumably expressed in an abrupt lake level drop (within 45 years) and lake level rise (within 250 years) in Chew Bahir. After the return to full humid conditions, the AHP main phase was interrupted by four dry spells at 11-10.7, 9.8-9.0, 7.8-7.5 and 7.1-6.8 ka BP. Those dry events are also reflected in records from lakes Turkana and paleo-lake Suguta (Figure 8), Mount Kilimanjaro (Thompson et al., 2002), Arabia (Fleitmann et al., 2003), as well as marine records off the NE coast of Africa (e.g., Gupta et al., 2003). Most of these dry episodes have lasted around 300 years. We expect, from a modeling perspective, these dry spells to have been long enough to desiccate paleo-lake Chew Bahir completely.

Trauth et al. (2018) highlights fourteen 20-80 years lasting dry events within the K-proxy record during the overall gradual termination of the AHP. According to our LBM, decadal dry events of 40 years or longer were able to dry up the Chew Bahir basin completely. Dry periods of 40 years or shorter still caused a considerable reduction in lake level though not a complete desiccation (Figure 8). Over the entire length of the AHP termination, Chew Bahir appears to have been under severe desiccation pressure. Such rainfall variability was also recorded in stalagmites in the near-by south-eastern rift shoulders of 
Ethiopia during times of a progressively drier climate (Baker et al., 2010). However, short-term precipitation changes may have filled lakes Abaya and Chamo up to their shallow overflow sills and provided Chew Bahir every now and then with enough water to delay the drying up process. The short-term flickers at the end of the AHP suggest, that paleo-lake Chew Bahir had not enough time between those flickers to have reached the overflow sill again. This assumption is supported by the finding of van der Lubbe et al. (2017), who used strontium isotopes as a water provenance proxy over the AHP and found no indication of a contribution of Chew Bahir water after $6 \mathrm{ka}$ into Lake Turkana (Figure 8F).

The recent dry period after the termination of the AHP, which has left the Chew Bahir basin dry for most of the time, is interrupted by brief excursions to wetter conditions at 3, 2.2, and $1.3 \mathrm{ka}$ BP (Figure 8A). Such a lowering of $\mathrm{K}$ concentration in the sediments of paleo-lake Chew Bahir points toward a lake transgression and thus a positive water budget during this time. Based on the results of our LBM, we conclude that even though the duration of these events would have allowed a rise of Chew Bahir's paleolake level, it is unlikely that the lake has reached maximum lake depths during these short-term humid episodes. This conclusion is supported by two arguments: (1) We expect a different climatic forcing mechanism than during the AHP, where a precession minimum caused enhanced humidity and the shift of rain belts over the study region (e.g., Costa et al., 2014; Junginger et al., 2014; Bloszies et al., 2015; Beck et al., 2019). For the past $\sim 5 \mathrm{ka}$, for example, short-term changes in sea surface temperatures and associated circulation systems could account for these short-term increases in precipitation (e.g., Nicholson, 2017; Bayon et al., 2019). (2) The second argument against maximum water levels in Chew Bahir is that $\mathrm{K}$ concentrations do not reach AHP minima. A clear signal whether our assumption, that lake Chew Bahir has not reached its overflow level, is true may only be proved by poxies that could reflect paelo-water provenance, such as strontium isotopes in aquatic fossils, as van der Lubbe et al. (2017) have shown. In summary, paleolake Chew Bahir was a large paleo-lake during the AHP that dried up abruptly at least 19 times within decades resulting in a desert-like rift floor similar to today. Such rapid environmental changes must have had a tremendous impact on the biosphere including humans.

\section{Implications for Human Adaptations}

A first attempt of comparing an available archaeological record from hypothesized refuge areas in the region with inferred phases of climatic stress from the Chew Bahir K-proxy record was made by Foerster et al. $(2015,2016)$ for the last $20 \mathrm{ka}$. The study used scarce but available radiocarbon frequencies of documented archaeological sites in the lush mountainous regions of SW Ethiopia as a possible indicator for changes in settlement activities in the highlands during dry periods in the lowlands, which are indicated by high $\mathrm{K}$ content in the drill core sediments of Chew Bahir (note inverse scale, Figure 8). Even though age model uncertainties, the indefinite incompleteness and natural biases in the archaeological record naturally constrain the possibility to directly correlate climatic and archaeological data sets (see Foerster et al., 2015, 2016) and references therein), the patterns found in the comparative study are a valuable starting point to indirectly infer shifts in human settlement activity, bearing the role of external factors in mind. The results tentatively suggest that both, long and short-term climatic change could have affected settlement patterns and cultural innovation differently, though the factor of human decision-making within environmental boundaries played an important but further incalculable role (Foerster et al., 2015).

On the one hand, short-term episodes of pronounced aridity in the lower elevated lake basins, such as Chew Bahir could have been a push-factor for a refugium-directed vertical movement of groups with highly mobile hunter-gatherers (Figure 8C). A now further specified variable is the climatic component in this comparison as shown in our study. The Southern Ethiopian Rift has responded sensitively to even shorter dry spells, so that living conditions would have deteriorated quickly when the rift floor became too dry. One of the reasons why hunter-gatherers might have returned to the South Ethiopian Rift region after such dry spells, could have been their dietary style at that time, that was mainly devoted to fishing (e.g., Owen et al., 1982; Hildebrand et al., 2018). The long-term transitions, on the other hand, driven by changes in orbital controlled insolation, could have fueled cultural adaptation and significant changes in the social organization within groups. Only after the gradual end of the AHP with the near-desiccation of almost all lakes in the Kenyan and Ethiopian rift over a longer period ( $>1,000$ years), a cultural transition from hunter-gathering to pastoralism occurred (e.g., Marshall and Hildebrand, 2002; Garcin et al., 2012; Lesur et al., 2014). The change from fishing to herding seems to have been a dynamic process, since the introduction of cattle was catalyzed by the immigration of herders that were escaping the progressively drying Sahara region, where pastoralism had been introduced much earlier (e.g., Kuper and Kröpelin, 2006; Hildebrand and Grillo, 2012). The dried up lake beds and former lake margins could have provided new land and grazing grounds for this new life style, which also made people independent from fishing (e.g., Garcin et al., 2012).

Trauth et al. (2010) introduced the theoretical concept of allopatric speciation through precession forced long-term (>10,000 years) population separation and remixing within the EARS due to appearing and disappearing rift lakes. Based on our study results, the Chew Bahir, Abaya, and Chamo basins can be excluded from this concept, due to their extreme sensitive amplifier lake characteristics. We expect, from a modeling perspective, that these lakes reacted on much shorter time scales $(<100 \mathrm{a})$, suggesting that intensive adaption was required from humans living at the lakes margins (cultural buffering; GalwayWitham et al., 2019). One of those adaptive strategies could have been short-term migration, either vertically to the nearby more humid higher elevated grounds (Foerster et al., 2015; Ossendorf et al., 2019) or longitudinally and latitudinally to lake or river refugia that were not affected by the dry spells. Both would have contributed to a periodic cultural and genetic exchange, which is thought to be one of the key drivers in cultural innovation and, on longer time scales, evolution (Lahr and Foley, 1998; 
Scerri et al., 2018; Galway-Witham et al., 2019), with innovations being generally favored by the exchange of cultural information (Ackermann et al., 2016).

\section{CONCLUSION}

We developed a comprehensive Lake Balance Model (LBM) for the southern Ethiopian rift with focus on paleo-lake Chew Bahir and its catchment as a first contribution to better understand the potential response of paleo-lake Chew Bahir to precipitation changes. We conclude that the following paleo-precipitation estimates would have been necessary to fill paleo-lake Chew Bahir until its overflow level: (1) the classic LBM approach resulted in a $6.5 \%$ (TS) precipitation increase, (2) the addition of a third rainy season in the region from July to September would cause a $6.9 \%\left(\mathrm{TS}_{\mathrm{CAB}}\right)$ increase, leading to a total of $\mathrm{TS}+\mathrm{TS}_{\mathrm{CAB}}=13.4 \%$. (3) The inclusion of vegetation feedback of $+7-15 \%$, resulted in an additional precipitation, which sums up to a robust estimate of $\sim 20-30 \%$ increased precipitation compared to the modern day amount for the paleo-lake Chew Bahir during the African Humid Period. We furthermore determined the amplifier lake characteristics of Lakes Abaya $(\mathrm{HI}=0.25, \mathrm{AI}=1.72)$, Chamo $(\mathrm{HI}=0.15, \mathrm{AI}=1.33)$ and Chew Bahir $(\mathrm{HI}=0.23, \mathrm{AI}=0.83)$. We found that the sensitivity of lake levels is greatly increased during periods of high humidity due to overflowing lakes along the EARS axis and enhanced surface flow. Such additional water resources should be taken into account in the analysis of the paleo-hydrology of other lakes in the EARS when abrupt or gradual changes in the proxies are observed. Accordingly, we implemented all additional factors in our new LBM and were able to calculate lake level response times to abrupt and gradual precipitation changes and characterize lake level changes from K-proxy changes in a drill core from Chew Bahir. Based on our LBM results, we can now support the proposed abruptness of the onset of the AHP in southern Ethiopia by Trauth et al. (2018), similar to the beginning and end of the millennial-scale dry episode during the Younger Dryas. The results of our LBM furthermore support the gradual termination of the AHP, with the model indicating that the reported $20-80$ years lasting dry events that are punctuating the termination could have been

\section{REFERENCES}

Ackermann, R. R., Mackay, A., and Arnold, M. L. (2016). The hybrid origin of "modern" humans. Evol. Biol. 43, 1-11. doi: 10.1007/s11692-015-9348-1

Allen, R. G., Tasumi, M., Morse, A., Trezza, R., Wright, J. L., Bastiaanssen, W., et al. (2007). Satellite-based energy balance for mapping evapotranspiration with internalized calibration (METRIC) - applications. J. Irrig. Drainage Eng. 133, 395-406. doi: 10.1061/(ASCE)0733-9437(2007)133:4(395)

Asrat, A., Baker, A., Mohammed, M. U., Leng, M. J., Calsteren, P. V., and Smith, C. (2007). A high-resolution multi-proxy stalagmite record from Mechara, Southeastern Ethiopia: palaeohydrological implications for speleothem palaeoclimate reconstruction. J. Quat. Sci. 22, 53-63. doi: 10.1002/jqs.1013

Awulachew, S. B. (2006). Investigation of physical and bathymetric characteristics of Lakes Abaya and chamo, Ethiopia, and their management implications. Lakes Reserv. Res. Manag. 11, 133-140. doi: 10.1111/j.1440-1770.2006.00300.x

Bachofer, F., Quénéhervé, G., Maerker, M., and Hochschild, V. (2015). Comparison of SVM and boosted regression trees for the delineation of lacustrine sediments using multispectral ASTER data and topographic indices in the Lake able to dry up the paleo-lake completely, when caused by abrupt precipitation changes.

\section{DATA AVAILABILITY STATEMENT}

The hydro-balance model coded in $\mathrm{R}$ is available at GitHub (https://github.com/MLFischer/Lake-Balance-Model, 03/2019).

\section{AUTHOR CONTRIBUTIONS}

This study was designed and financed by $\mathrm{AJ}$ and MF. MF developed and performed the final LBM. MM, FB, $\mathrm{VF}, \mathrm{MT}$, and AJ contributed the data and analysis tools. All authors contributed to the article and approved the submitted version.

\section{FUNDING}

The research has been funded by the Ministry of Culture and Science (MWK) of Baden Württemberg, Germany, the Stiftung der deutschen Wirtschaft and the Open Access Publishing Fund of the University of Tübingen.

\section{ACKNOWLEDGMENTS}

This study was conducted as part of the project Wet Feet or Walking on Sunshine of AJ funded by the Ministry of Culture and Science (MWK) of Baden Württemberg, Germany and by Stiftung der deutschen Wirtschaft financing the doctoral project of MF. We thank the three reviewers for their helpful comments, which improved the quality of this manuscript. We also acknowledge support by the Open Access Publishing Fund of the University of Tübingen. We thank Bodo Bookhagen from the University of Potsdam for his advises in using MODIS data. We were also grateful for valuable insights from long-term field experience in southern Ethiopia given by Frank Schäbitz from the University of Cologne and Henry Lamb from the University of Aberystwyth. Walter Düsing (University of Potsdam) and Fabian Sittaro (University of Leipzig): thank you for your inspiring discussions about paleo-data analysis, hydro-balance models, vegetation models, and life. doi: $10.1127 / \mathrm{pfg} / 2015 / 0251$

Baker, A., Asrat, A., Fairchild, I. J., Leng, M. J., Thomas, L., Widmann, M., et al. (2010). Decadal-scale rainfall variability in Ethiopia recorded in an annually laminated, holocene-age, stalagmite. Holocene 20, 827-836. doi: $10.1177 / 0959683610365934$

Barker, P. A., Talbot, M. R., Street-Perrott, F. A., Marret, F., Scourse, J., Odada, E. O. (2004). "Late Quaternary climatic variability in intertropical Africa," in Past Climate Variability through Europe and Africa, Developments in Paleoenvironmental Research, vol. 6. eds R. W. Battarbee, F. Gasse, C. E. Stickley (Dordrecht: Springer), 117-138. doi: 10.1007/978-1-4020-2121-3_7

Bastiaanssen, W. G. (2000). SEBAL-based sensible and latent heat fluxes in the irrigated Gediz Basin, Turkey. J. Hydrol. 229, 87-100. doi: 10.1016/S0022-1694(99)00202-4

Bastiaanssen, W. G., Menenti, M., Feddes, R. A., and Holtslag, A. A. M. (1998a). A remote sensing surface energy balance algorithm for land (SEBAL). 1. Formulation. J. Hydrol. 212, 198-212. doi: 10.1016/S0022-1694(98) 00253-4 
Bastiaanssen, W. G., Pelgrum, H., Wang, J., Ma, Y., Moreno, J. F., Roerink, G. J., et al. (1998b). A remote sensing surface energy balance algorithm for land (SEBAL).: Part 2: validation. J. Hydrol. 212, 213-229. doi: 10.1016/S0022-1694(98)00254-6

Bastiaanssen, W. G. M., Noordman, E. J. M., Pelgrum, H., Davids, G., Thoreson, B. P., and Allen, R. G. (2005). SEBAL model with remotely sensed data to improve water-resources management under actual field conditions. J. Irrig. Drainage Eng. 131, 85-93. doi: 10.1061/(ASCE)0733-9437(2005)131:1(85)

Bayon, G., Schefuß, E., Dupont, L., Borges, A. V., Dennielou, B., Lambert, T., et al. (2019). The roles of climate and human land-use in the late Holocene rainforest crisis of Central Africa. Earth Planet. Sci. Lett. 505, 30-41. doi: 10.1016/j.epsl.2018.10.016

Beck, C. C., Feibel, C. S., Wright, J. D., and Mortlock, R. A. (2019). Onset of the African humid period by $13.9 \mathrm{kyr}$ BP at kabua gorge, turkana Basin, Kenya. Holocene 29, 1011-1019. doi: 10.1177/0959683619831415

Belete, A. (2009). Climate change impact on lake abaya water level (M.Sc. thesis), Addis Ababa University, Ethiopia. Available online at: http://etd.aau.edu. et/dspace/bitstream/123456789/2635/1/ 17730248189668230838464212617211563806

Berger, A., and Loutre, M. F. (1991). Insolation values for the climate of the last 10 million years. Quat. Sci. Rev. 10, 297-317. doi: 10.1016/0277-3791(91)90033-Q

Bergner, A. G., Trauth, M. H., and Bookhagen, B. (2003). Paleoprecipitation estimates for the Lake Naivasha basin (Kenya) during the last 175 ky using a lake-balance model. Global Planet Change. 36, 117-136. doi: 10.1016/S0921-8181(02)00178-9

Berke, M. A., Johnson, T. C., Werne, J. P., Grice, K., Schouten, S., and Damsté, J. S. S. (2012b). Molecular records of climate variability and vegetation response since the late pleistocene in the lake victoria basin, East Africa. Quat. Sci. Rev. 55, 59-74. doi: 10.1016/j.quascirev.2012.08.014

Berke, M. A., Johnson, T. C., Werne, J. P., Schouten, S., and Damsté, J. S. S. (2012a). A mid-Holocene thermal maximum at the end of the African Humid Period. Earth Planet. Sci. Lett. 351-352, 95-104. doi: 10.1016/j.epsl.2012.07.008

Blodgett, T. A., Isacks, B. L., and Lenters, J. D. (1997). Constraints on the origin of paleolake expansions in the central andes. Earth Interact. 1, 1-28.doi: 10.1175/ 1087-3562(1997)001<0001:COTOOP > 2.3.CO;2

Bloszies, C., Forman, S. L., and Wright, D. K. (2015). Water level history for lake turkana, Kenya in the past 15,000 years and a variable transition from the African humid period to holocene aridity. Glob. Planet. Change 132, 64-76. doi: 10.1016/j.gloplacha.2015.06.006

Bookhagen, B. (in review). High resolution spatiotemporal distribution of rainfall seasonality and extreme events based on a 12-year TRMM time series, in review. [Data set] Available online at: http://www.geog.ucsb.edu/ bodo/ TRMM/ (accessed Agust 1, 2018).

Bookhagen, B., Haselton, K., and Trauth, M. H. (2001). Hydrological modelling of a pleistocene landslide-dammed lake in the santa maria basin, NW Argentina. Palaeogeogr. Palaeoclimatol. Palaeoecol. 169, 113-127. doi: 10.1016/S0031-0182(01)00221-8

Borchardt, S., and Trauth, M. H. (2012). Remotely-sensed evapotranspiration estimates for an improved hydrological modeling of the early holocene megalake suguta, northern Kenya Rift. Palaeogeogr. Palaeoclimatol. Palaeoecol. 361, 14-20. doi: 10.1016/j.palaeo.2012.07.009

Brooks, N. (2006). Cultural responses to aridity in the middle holocene and increased social complexity. Quat. Int. 151, 29-49. doi: 10.1016/j.quaint.2006.01.013

Brutsaert, W. (1982). Evaporation Into the Atmosphere: Theory, History, and Applications. Dordrecht: Reidel.

Camberlin, P. (1997). Rainfall anomalies in the source region of the Nile and their connection with the Indian summer monsoon. J. Clim. 10, 1380-1392. doi: 10.1175/1520-0442(1997)010<1380:RAITSR >2.0.CO;2

Chalié, F., and Gasse, F. (2002). Late glacial-holocene diatom record of water chemistry and lake level change from the tropical east african rift lake abiyata (Ethiopia). Palaeogeogr. Palaeoclimatol. Palaeoecol. 187, 259-283. doi: 10.1016/S0031-0182(02)00480-7

Chernet, T. (1993). Hydrogeology of Ethiopia and Water Resources Development. Addis Ababa: EIGS.

Claussen, M., Dallmeyer, A., and Bader, J. (2017). "Theory and modeling of the African humid period and the green Sahara," in Oxford Research Encyclopedia of Climate Science. doi: 10.1093/acrefore/9780190228620.013.532
Collins, J. A., Prange, M., Caley, T., Gimeno, L., Beckmann, B., Mulitza, S., et al. (2017). Rapid termination of the african humid period triggered by northern high-latitude cooling. Nat. Commun. 8:1372. doi: 10.1038/s41467-017-01454-y

Costa, K., Russell, J., Konecky, B., and Lamb, H. (2014). Isotopic reconstruction of the african humid period and congo air boundary migration at lake tana, Ethiopia. Quat. Sci. Rev. 83, 58-67. doi: 10.1016/j.quascirev.2013.10.031

Damsté, J. S. S., Ossebaar, J., Schouten, S., and Verschuren, D. (2012). Distribution of tetraether lipids in the 25-ka sedimentary record of Lake Challa: extracting reliable TEX86 and MBT/CBT palaeotemperatures from an equatorial African lake. Quat. Sci. Rev. 50, 43-54. doi: 10.1016/j.quascirev.2012.07.001

Davidson, A. (1983). The Omo river project, reconnaissance geology and geochemistry of parts of Ilubabor, kefa, gemu gofa and sidamo, Ethiopia. Ethiop. Inst. Geol. Surv. Bull. 2, 1-89.

De Bruin, H. A. R., and Stricker, J. N. M. (2000). Evaporation of grass under non-restricted soil moisture conditions. Hydrol. Sci. J. 45, 391-406. doi: 10.1080/02626660009492337

Dee, S. G., Russell, J. M., Morrill, C., Chen, Z., and Neary, A. (2018). PRYSM v2.0: a proxy system model for lacustrine archives. Paleoceanogr. Paleoclimatol. 33, 1250-1269. doi: 10.1029/2018PA003413

deMenocal, P., Ortiz, J., Guilderson, T., Adkins, J., Sarnthein, M., Baker, L., et al. (2000). Abrupt onset and termination of the African Humid Period: rapid climate responses to gradual insolation forcing. Quat. Sci. Rev. 19, 347-361. doi: 10.1016/S0277-3791(99)00081-5

demenocal, P. B. (1995). Plio-pleistocene African climate. Science 270, 53-59. doi: $10.1126 /$ science.270.5233.53

Didan, K. (2015). MOD13Q1 MODIS/Terra Vegetation Indices 16-Day L3 Global $250 m$ SIN Grid V006 [Data set]. NASA EOSDIS Land Processes DAAC. Available online at: https://doi.org/10.5067/MODIS/MOD13Q1.006 (accessed August 1, 2018).

Drake, N. A., Breeze, P., and Parker, A. (2013). Palaeoclimate in the saharan and arabian deserts during the middle palaeolithic and the potential for hominin dispersals. Quat. Int. 300, 48-61. doi: 10.1016/j.quaint.2012.12.018

Dühnforth, M., Bergner, A. G., and Trauth, M. H. (2006). Early holocene water budget of the nakuru-elmenteita basin, central Kenya Rift. J. Paleolimnol. 36, 281-294. doi: 10.1007/s10933-006-9003-Z

Ebinger, C. J., Yemane, T., Woldegabriel, G., Aronson, J. L., and Walter, R. C. (1993). Late eocene-recent volcanism and faulting in the southern main Ethiopian rift. J. Geol. Soc. 150, 99-108. doi: 10.1144/gsjgs.150.1.0099

Evans, M. N., Tolwinski-Ward, S. E., Thompson, D. M., and Anchukaitis, K. J. (2013). Applications of proxy system modeling in high resolution paleoclimatology. Quat. Sci. Rev. 76, 16-28. doi: 10.1016/j.quascirev.2013.05.024

Fleitmann, D., Burns, S. J., Mudelsee, M., Neff, U., Kramers, J., Mangini, A., et al. (2003). Holocene forcing of the Indian monsoon recorded in a stalagmite from southern Oman. science 300, 1737-1739. doi: 10.1126/science.1083130

Foerster, V., Deocampo, D. M., Asrat, A., Günter, C., Junginger, A., Krämer, K. H., et al. (2018). Towards an understanding of climate proxy formation in the chew bahir basin, southern Ethiopian Rift. Palaeogeogr. Palaeoclimatol. Palaeoecol. 501, 111-123. doi: 10.1016/j.palaeo.2018.04.009

Foerster, V., Junginger, A., Langkamp, O., Gebru, T., Asrat, A., Umer, M., et al. (2012). Climatic change recorded in the sediments of the chew bahir basin, southern Ethiopia, during the last 45,000 years. Quat. Int. 274, 25-37. doi: 10.1016/j.quaint.2012.06.028

Foerster, V., Vogelsang, R., Junginger, A., Asrat, A., Lamb, H. F., Schaebitz, F., et al. (2015). Environmental change and human occupation of southern Ethiopia and northern Kenya during the last 20,000 years. Quat. Sci. Rev. 129, 333-340. doi: 10.1016/j.quascirev.2015.10.026

Foerster, V., Vogelsang, R., Junginger, A., Asrat, A., Lamb, H. F., Schaebitz, F., et al. (2016). Reply to the comment on "Environmental change and human occupation of southern Ethiopia and northern Kenya during the last 20,000 years. Quaternary Science Reviews 129: 333-340". Quat. Sci. Revi. 141, 130-133. doi: 10.1016/j.quascirev.2016.04.003

Friedl, M. A., Sulla-Menashe, D., Tan, B., Schneider, A., Ramankutty, N., Sibley, A., et al. (2010). MODIS Collection 5 global land cover: algorithm refinements and characterization of new datasets. Remote Sens. Environ. 114, 168-182. doi: 10.1016/j.rse.2009.08.016

Friis, I., Demissew, S., and Breugel, P. V. (2010). Atlas of the potential vegetation of Ethiopia. Biol. Skrif. 58, 1-307. doi: 10.1093/aob/mcq242 
Funk, C., Dettinger, M. D., Michaelsen, J. C., Verdin, J. P., Brown, M. E., Barlow, M., et al. (2008). Warming of the Indian ocean threatens eastern and southern african food security but could be mitigated by agricultural development. Proc. Natl. Acad. Sci. U.S.A. 105, 11081-11086. doi: 10.1073/pnas.0708196105

Galway-Witham, J., Cole, J., and Stringer, C. (2019). Aspects of human physical and behavioural evolution during the last 1 million years. J. Quat. Sci. 34, 355-378. doi: $10.1002 /$ jqs. 3137

Garcin, Y., Junginger, A., Melnick, D., Olago, D. O., Strecker, M. R., and Trauth, M. H. (2009). Late pleistocene-holocene rise and collapse of lake suguta, northern Kenya Rift. Quat. Sci. Rev. 28, 911-925. doi: 10.1016/j.quascirev.2008.12.006

Garcin, Y., Melnick, D., Strecker, M. R., Olago, D., and Tiercelin, J. J. (2012). East African mid-holocene wet-dry transition recorded in palaeo-shorelines of lake turkana, northern Kenya Rift. Earth Planet. Sci. Lett. 331, 322-334. doi: $10.1016 /$ j.epsl.2012.03.016

Gasse, E., and Street, F. A. (1978). Late Quaternary lake-level fluctuations and environments of the northern Rift Valley and Afar region (Ethiopia and Djibouti). Palaeogeogr. Palaeoclimatol. Palaeoecol. 24, 279-325. doi: 10.1016/0031-0182(78)90011-1

Gillespie, R., Street-Perrott, F. A., and Switsur, R. (1983). Post-glacial arid episodes in Ethiopia have implications for climate prediction. Nature 306:680. doi: 10.1038/306680a0

Gupta, A. K., Anderson, D. M., and Overpeck, J. T. (2003). Abrupt changes in the Asian southwest monsoon during the Holocene and their links to the North Atlantic Ocean. Nature 421:354. doi: 10.1038/nature01340

Hastenrath, S., and Kutzbach, J. E. (1983). Paleoclimatic estimates from water and energy budgets of East African lakes. Quat. Res. 19, 141-153. doi: 10.1016/0033-5894(83)90001-7

Hildebrand, E. A., and Grillo, K. M. (2012). Early herders and monumental sites in eastern Africa: dating and interpretation. Antiquity 86, 338-352. doi: $10.1017 /$ S0003598X00062803

Hildebrand, E. A., Grillo, K. M., Sawchuk, E. A., Pfeiffer, S. K., Conyers, L. B., Goldstein, S. T., et al. (2018). A monumental cemetery built by eastern Africa's first herders near Lake Turkana, Kenya. Proc. Natl. Acad. Sci. U.S.A. 115, 8942-8947. doi: 10.1073/pnas.1721975115

Honegger, M., and Williams, M. (2015). Human occupations and environmental changes in the Nile valley during the holocene: the case of kerma in upper nubia (northern Sudan). Quat. Sci. Rev. 130, 141-154. doi: 10.1016/j.quascirev.2015.06.031

Junginger, A. (2011). East African climate variability on different time scales: the Suguta Valley in the African-Asian Monsoon Domain (Doctoral dissertation), University of Potsdam, Germany.

Junginger, A., Roller, S., Olaka, L. A., and Trauth, M. H. (2014). The effects of solar irradiation changes on the migration of the congo air boundary and water levels of paleo-lake suguta, northern Kenya Rift, during the African humid period (15-5 ka BP). Palaeogeogr. Palaeoclimatol. Palaeoecol. 396, 1-16. doi: 10.1016/j.palaeo.2013.12.007

Junginger, A., and Trauth, M. H. (2013). Hydrological constraints of paleo-lake suguta in the northern kenya rift during the African humid period (15-5 ka BP). Glob. Planet. Change 111, 174-188. doi: 10.1016/j.gloplacha.2013.09.005

Kassa, T. G. (2015). Holocene Environmental History of Lake Chamo, South Ethiopia (Doctoral dissertation), University of Cologne, Germany.

Kebede, S., and Travi, Y. (2012). Origin of the $\delta 18 \mathrm{O}$ and $\delta 2 \mathrm{H}$ composition of meteoric waters in Ethiopia. Quat. Int. 257, 4-12. doi: 10.1016/j.quaint.2011.09.032

Kiptala, J. K., Mohamed, Y., Mul, M. L., and Van der Zaag, P. (2013). Mapping evapotranspiration trends using MODIS and SEBAL model in a data scarce and heterogeneous landscape in Eastern Africa. Water Resour. Res. 49, 8495-8510. doi: 10.1002/2013WR014240

Kirkby, M. J., and Beven, K. J. (1979). A physically based, variable contributing area model of basin hydrology. Hydrol. Sci. J. 24, 43-69. doi: $10.1080 / 02626667909491834$

Kniess, U. (2006). Hydrologische Modellierung im Zentralen Kenya-Rift (Unpublished Diploma thesis), University of Potsdam, Germany.

Kuper, R., and Kröpelin, S. (2006). Climate-controlled Holocene occupation in the Sahara: motor of Africa's evolution. Science 313, 803-807. doi: 10.1126/science.1130989

Lahr, M., and Foley, R. A. (1998). Towards a theory of modern human origins: geography, demography, and diversity in recent human evolution. Am. J. Phys. Anthropol. 107, 137-176. doi: 10.1002/(SICI)10968644(1998)107:27+<137::AID-AJPA6>3.0.CO;2-Q
Lamb, A. L., Leng, M. J., Lamb, H. F., and Mohammed, M. U. (2000). A 9000-year oxygen and carbon isotope record of hydrological change in a small Ethiopian crater lake. Holocene 10, 167-177. doi: 10.1191/095968300677444611

Lamb, A. L., Leng, M. J., Mohammed, M. U., and Lamb, H. F. (2004). Holocene climate and vegetation change in the main ethiopian rift valley, inferred from the composition (C/N and $\delta 13 \mathrm{C})$ of lacustrine organic matter. Quat. Sci. Rev. 23, 881-891. doi: 10.1016/j.quascirev.2003.06.010

Lamb, P. J., Bell, M. A., and Finch, J. D. (1998). "Varibility of Sahelian disturbance lines and rainfall during 1951-87," in Water Resources Variability in Africa during XXth Century, eds E. Servat et al. (IAHS), 19-26.

Lario, J., Sanchez-Moral, S., Fernandez, V., Jimeno, A., and Menendez, M. (1997). Palaeoenvironmental evolution of the blue Nile (Central Sudan) during the early and mid-holocene (Mesolithic-Neolithic transition). Quat. Sci. Rev. 16, 583-588. doi: 10.1016/S0277-3791(96)00053-4

Larrasoaña, J. C., Roberts, A. P., and Rohling, E. J. (2013). Dynamics of green Sahara periods and their role in hominin evolution. PLOS ONE 8:e76514. doi: 10.1371/journal.pone.0076514

Lenters, J. D., and Cook, K. H. (1999). Summertime precipitation variability over South America: Role of the large-scale circulation. Monthly Weather Rev. 127, 409-431. doi: 10.1175/1520-0493(1999)127<0409:SPVOSA>2.0.CO;2

Lesur, J., Hildebrand, E. A., Abawa, G., and Gutherz, X. (2014). The advent of herding in the horn of africa: new data from Ethiopia, Djibouti and Somaliland. Quat. Int. 343, 148-158. doi: 10.1016/j.quaint.2013.11.024

Levin, N. E., Zipser, E. J., and Cerling, T. E. (2009). Isotopic composition of waters from Ethiopia and Kenya: insights into moisture sources for eastern Africa. J. Geophys. Res. Atmospheres. 114:D23. doi: 10.1029/2009JD012166

Liu, C., Ikeda, K., Rasmussen, R., Barlage, M., Newman, A. J., Prein, A. F., et al. (2017). Continental-scale convection-permitting modeling of the current and future climate of North America. Clim. Dynam. 49, 71-95. doi: 10.1007/s00382-016-3327-9

Loomis, S. E., Russell, J. M., Eggermont, H., Verschuren, D., and Damsté, J. S. S. (2014). Effects of temperature, $\mathrm{pH}$ and nutrient concentration on branched GDGT distributions in East African lakes: Implications for paleoenvironmental reconstruction. Org. Geochem. 66, 25-37. doi: 10.1016/j.orggeochem.2013.10.012

Loomis, S. E., Russell, J. M., Ladd, B., Street-Perrott, F. A., and Damsté, J. S. S. (2012). Calibration and application of the branched GDGT temperature proxy on East African lake sediments. Earth Planet. Sci. Lett. 357, 277-288. doi: 10.1016/j.epsl.2012.09.031

Loomis, S. E., Russell, J. M., and Lamb, H. F. (2015). Northeast African temperature variability since the Late Pleistocene. Palaeogeogr. Palaeoclimatol. Palaeoecol. 423, 80-90. doi: 10.1016/j.palaeo.2015.02.005

Losgedaragh, S. Z., and Rahimzadegan, M. (2018). Evaluation of SEBS, SEBAL, and METRIC models in estimation of the evaporation from the freshwater lakes (Case study: Amirkabir dam, Iran). J. Hydrol. 561, 523-531. doi: 10.1016/j.jhydrol.2018.04.025

Manning, K., and Timpson, A. (2014). The demographic response to Holocene climate change in the Sahara. Quat. Sci. Rev. 101, 28-35. doi: 10.1016/j.quascirev.2014.07.003

Marchant, R., Richer, S., Boles, O., Capitani, C., Courtney-Mustaphi, C. J., Lane, P., et al. (2018). Drivers and trajectories of land cover change in East Africa: Human and environmental interactions from 6000 years ago to present. Earth Sci. Rev. 178, 322-378. doi: 10.1016/j.earscirev.2017.12.010

Marshall, F., and Hildebrand, E. (2002). Cattle before crops: the beginnings of food production in Africa. J. World Prehistory 16, 99-143. doi: 10.1023/A:1019954903395

Marshall, M. H., Lamb, H. F., Davies, S. J., Leng, M. J., Kubsa, Z., Umer, M., et al. (2009). Climatic change in northern Ethiopia during the past 17,000 years: a diatom and stable isotope record from Lake Ashenge. Palaeogeogr. Palaeoclimatol. Palaeoecol. 279, 114-127. doi: 10.1016/j.palaeo.2009.05.003

Merwade, V. (2012). Watershed and Stream Network DelineationUsing Arc Hydro Tools. Available online at: https://web.ics.purdue.edu/ vmerwade/education/ terrain_processing.pdf (accessed August 2018).

Mkhwanazi, M., Chavez, J. L., and Andales, A. A. (2015). SEBAL-A: A remote sensing ET algorithm that accounts for advection with limited data. Part I: Development and validation. Remote Sens. 7, 15046-15067. doi: 10.3390/rs71115046

New, M., Lister, D., Hulme, M., and Makin, I. (2002). A high-resolution data set of surface climate over global land areas. Clim. Res. 21, 1-25. doi: $10.3354 / \mathrm{cr} 021001$ 
Nicholson, S. E. (1996). A review of climate dynamics and climate variability in Eastern Africa. Limnol. Climatol. Paleoclimatol. 25-56. doi: 10.1201/9780203748978-2

Nicholson, S. E. (2000). The nature of rainfall variability over Africa on time scales of decades to millenia. Glob. Planet. Change 26, 137-158. doi: 10.1016/S0921-8181(00)00040-0

Nicholson, S. E. (2017). Climate and climatic variability of rainfall over eastern Africa. Rev. Geophys. 55, 590-635. doi: 10.1002/2016RG000544

Olaka, L. A. (2011). Hydrology across scales: sensitivity of East African lakes to climate changes (Doctoral dissertation), Universität Potsdam, Germany.

Olaka, L. A., Odada, E. O., Trauth, M. H., and Olago, D. O. (2010). The sensitivity of East African rift lakes to climate fluctuations. J. Paleolimnol. 44, 629-644. doi: 10.1007/s10933-010-9442-4

Ossendorf, G., Groos, A. R., Bromm, T., Tekelemariam, M. G., Glaser, B., Lesur, J., et al. (2019). Middle stone age foragers resided in high elevations of the glaciated bale mountains, Ethiopia. Science 365, 583-587. doi: 10.1126/science.aaw8942

Owen, R. B., Barthelme, J. W., Renaut, R. W., and Vincens, A. (1982). Palaeolimnology and archaeology of holocene deposits north-east of lake turkana, Kenya. Nature 298:523. doi: 10.1038/298523a0

Pike, R. J., and Wilson, S. E. (1971). Elevation-relief ratio, hypsometric integral, and geomorphic area-altitude analysis. Geol. Soc. Am. Bull. 82, 1079-1084. doi: 10.1130/0016-7606(1971)821079:ERHIAG2.0.CO;2

Platnick, S., Ackerman, S. A., King, M. D., Meyer, K., Menzel, W. P., Holz, R. E., et al. (2015). MODIS atmosphere L2 cloud product (06_L2), NASA MODIS Adaptive Processing System. Goddard Space Flight Center. doi: 10.5067/MODIS/MYD06_L2.006

R Core Team (2019). R: A Language and Environment for Statistical Computing. Vienna: R Foundation for Statistical Computing. Available online at: http:// www.R-project.org/

Renssen, H., Brovkin, V., Fichefet, T., and Goosse, H. (2006). Simulation of the holocene climate evolution in northern Africa: the termination of the African humid period. Quat. Int. 150, 95-102. doi: 10.1016/j.quaint.2005. 01.001

Revel, M., Colin, C., Bernasconi, S., Combourieu-Nebout, N., Ducassou, E., Grousset, F. E., et al. (2014). 21,000 Years of Ethiopian African monsoon variability recorded in sediments of the western nile deep-sea fan. Reg. Environ. Change 14, 1685-1696. doi: 10.1007/s10113-014-0588-x

Richardson, J. L., and Dussinger, R. A. (1986). Paleolimnology of midelevation lakes in the Kenya Rift Valley. Hydrobiologia 143, 167-174. doi: 10.1007/BF00026659

Rowell, D. P., Booth, B. B., Nicholson, S. E., and Good, P. (2015). Reconciling past and future rainfall trends over East Africa. J. Clim. 28, 9768-9788. doi: 10.1175/JCLI-D-15-0140.1

Rucina, S. M., Muiruri, V. M., Kinyanjui, R. N., McGuiness, K., and Marchant, R. (2009). Late quaternary vegetation and fire dynamics on mount Kenya. Palaeogeogr. Palaeoclimatol. Palaeoecol. 283, 1-14. doi: 10.1016/j.palaeo.2009.08.008

Scerri, E. M., Thomas, M. G., Manica, A., Gunz, P., Stock, J. T., Stringer, C., et al. (2018). Did our species evolve in subdivided populations across Africa, and why does it matter? Trends Ecol. Evol. 33, 582-594. doi: 10.1016/j.tree.2018.05.005

Segele, Z. T., and Lamb, P. J. (2005). Characterization and variability of Kiremt rainy season over Ethiopia. Meteorol. Atmospher. Phys. 89, 153-180. doi: 10.1007/s00703-005-0127-x

Street-Perrott, F. A., Harrison, S. P. (1985). "Lake levels and climate reconstruction," in Paleoclimate Analysis and Modeling, ed A. D. Hecht (New York, NY: John Wiley), 291-340.

Telford, R. J., and Lamb, H. F. (1999). Groundwater-mediated response to Holocene climatic change recorded by the diatom stratigraphy of an Ethiopian crater lake. Quat. Res. 52, 63-75. doi: 10.1006/qres.1999.2034

Thompson, L. G., Mosley-Thompson, E., Davis, M. E., Henderson, K. A., Brecher, H. H., Zagorodnov, V. S., et al. (2002). Kilimanjaro ice core records: evidence of holocene climate change in tropical Africa. Science 298, 589-593. doi: $10.1126 /$ science. 1073198

Thornthwaite, C. W. (1948). An approach toward a rational classification of climate. Geogr. Rev. 38, 55-94. doi: 10.2307/210739

Thornthwaite, C. W., and Mather, J. R. (1955). The Water Balance. Centerton: Drexel Institute of Technology, Laboratory of Climatology.
Tierney, J. E., Smerdon, J. E., Anchukaitis, K. J., and Seager, R. (2013). Multidecadal variability in East African hydroclimate controlled by the Indian Ocean. Nature 493:389. doi: 10.1038/nature11785

Tiruneh, A. T. (2005). Water quality monitoring in lake abaya and lake chamo region (Doctoral dissertation), University of Siegen, Germany.

Trauth, M. H., Foerster, V., Junginger, A., Asrat, A., Lamb, H. F., and Schaebitz, F. (2018). Abrupt or gradual? Change point analysis of the late pleistoceneholocene climate record from chew bahir, southern Ethiopia. Quat. Res. 90, 321-330. doi: 10.1017/qua.2018.30

Trauth, M. H., Maslin, M. A., Deino, A. L., Junginger, A., Lesoloyia, M., Odada, E. O., et al. (2010). Human evolution in a variable environment: the amplifier lakes of Eastern Africa. Quat. Sci. Rev. 29, 2981-2988. doi: 10.1016/j.quascirev.2010.07.007

Umer, M., Lamb, H. F., Bonnefille, R., Lézine, A. M., Tiercelin, J. J., Gibert, E., et al. (2007). Late pleistocene and holocene vegetation history of the Bale mountains, Ethiopia. Quat. Sci. Rev. 26, 2229-2246. doi: 10.1016/j.quascirev.2007.05.004

van der Lubbe, H. J. L., Krause-Nehring, J., Junginger, A., Garcin, Y., Joordens, J. C. A., Davies, G. R., et al. (2017). Gradual or abrupt? Changes in water source of Lake Turkana (Kenya) during the African Humid Period inferred from Sr isotope ratios. Quat. Sci. Rev. 174, 1-12. doi: 10.1016/j.quascirev.2017.08.010

Vermote, E., and Wolfe, R. (2015). "MOD09GA MODIS/terra surface reflectance daily L2G global 1kmand 500m SIN grid V006 [Data set]," in NASA EOSDIS Land Processes DAAC. Available online at: https://doi.org/10.5067/MODIS/ MOD09GA.006 (accessed January 8, 2020).

Verschuren, D. (2004). "Decadal and century-scale climate variability in tropical Africa during the past 2000 years," in Past Climate Variability through Europe and Africa. Developments in Paleoenvironmental Research, vol 6, eds R. W. Battarbee, F. Gasse, C. E. Stickley (Dordrecht: Springer), 139-158. doi: 10.1007/978-1-4020-2121-3_8

Vincens, A., Buchet, G., Williamson, D., and Taieb, M. (2005). A 23,000 yr pollen record from Lake Rukwa (8S, SW Tanzania): new data on vegetation dynamics and climate in Central Eastern Africa. Rev. Palaeobot. Palynol. 137, 147-162. doi: 10.1016/j.revpalbo.2005.06.001

Viste, E. M. (2012). Moisture transport and precipitation in Ethiopia (Doctoral dissertation), University of Bergen, Norway.

Wagner, B., Wennrich, V., Viehberg, F., Junginger, A., Kolvenbach, A., Rethemeyer, J., et al. (2018). Holocene rainfall runoff in the central Ethiopian highlands and evolution of the River Nile drainage system as revealed from a sediment record from Lake Dendi. Glob. Planet. Change 163, 29-43. doi: 10.1016/j.gloplacha.2018.02.003

Wan, Z., Hook, S., and Hulley, G. (2015). "MOD11A1 MODIS/Terra land surface temperature/emissivity daily L3 global 1km SIN grid V006 [Data set]," in NASA EOSDIS Land Processes DAAC. Available online at: https://doi.org/10.5067/ MODIS/MOD11A1.006 (accessed January 8, 2020).

Wieringa, J. (1992). Updating the Davenport roughness classification. J. Wind Eng. Indus. Aerodyn. 41, 357-368. doi: 10.1016/0167-6105(92)90434-C

Williams, A. P., and Funk, C. (2011). A westward extension of the warm pool leads to a westward extension of the walker circulation, drying eastern Africa. Clim. Dyn. 37, 2417-2435. doi: 10.1007/s00382-010-0984-y

Zhang, X. C., Wu, J. W., Wu, H. Y., and Li, Y. (2011). Simplified SEBAL method for estimating vast areal evapotranspiration with MODIS data. Water Sci. Eng.4, 24-35. doi: 10.3882/j.issn.1674-2370.2011.01.003

Zielhofer, C., von Suchodoletz, H., Fletcher, W. J., Schneider, B., Dietze, E., Schlegel, M., et al. (2017). Millennial-scale fluctuations in Saharan dust supply across the decline of the African humid period. Quat. Sci. Rev. 171, 119-135. doi: 10.1016/j.quascirev.2017.07.010

Conflict of Interest: The authors declare that the research was conducted in the absence of any commercial or financial relationships that could be construed as a potential conflict of interest.

Copyright (C) 2020 Fischer, Markowska, Bachofer, Foerster, Asrat, Zielhofer, Trauth and Junginger. This is an open-access article distributed under the terms of the Creative Commons Attribution License (CC BY). The use, distribution or reproduction in other forums is permitted, provided the original author(s) and the copyright owner(s) are credited and that the original publication in this journal is cited, in accordance with accepted academic practice. No use, distribution or reproduction is permitted which does not comply with these terms. 